Saint Louis University School of Law

Scholarship Commons

All Faculty Scholarship

2012

\title{
The Regulation of Private Equity, Hedge Funds and State Funds
}

Henry Ordower

Saint Louis University School of Law

Follow this and additional works at: https://scholarship.law.slu.edu/faculty

Part of the Securities Law Commons

\section{Recommended Citation}

Ordower, Henry, The Regulation of Private Equity, Hedge Funds and State Funds (July 23, 2010). Saint Louis U. Legal Studies Research Paper No. 2010-22; Eddy Wymeersch, ed. Alternative Investment Fund Regulation, International Banking and Finance Law Series v. 16, Chap. 17, 401-431, 2012; 58 American Journal of Comparative Law - Supplement 1 295-321 (2010); Saint Louis U. Legal Studies Research Paper No. 2010-22. Also available at http://dx.doi.org/10.2139/ssrn.1654628

This Article is brought to you for free and open access by Scholarship Commons. It has been accepted for inclusion in All Faculty Scholarship by an authorized administrator of Scholarship Commons. For more information, please contact erika.cohn@slu.edu, ingah.daviscrawford@slu.edu. 


\section{S A I N T L O U IS \\ $\begin{array}{llllllllll}U & N & \text { I } & V & E & R & S & \text { I } & T & Y\end{array}$ \\ SCHOOL OF LAW}

\section{SAINT LOUIS UNIVERSITY SCHOOL OF LAW Legal Studies Research Paper Series}

Saint Louis University School of Law Legal Studies Research Paper Series No. 2010 - 22

The Regulation of Private Equity, Hedge Funds and State Funds

Working Paper Series

Henry Ordower

Saint Louis University School of Law

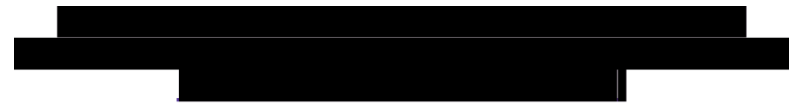




\title{
La Réglementation Des Fonds Spéculatifs/ The Regulation Of Private Equity, Hedge Funds And State Funds Revised United States National Report for the \\ XVIIIth Congress of the International Academy of Comparative Law
}

\author{
Henry Ordower, ${ }^{1}$ Professor of Law \\ Saint Louis University School of Law \\ United States Reporter
}

This United States report responds to a questionnaire that the general reporter for the project prepared. At the time the United States reporter prepared the report for the Congress, the United States Congress had not acted upon legislative proposals concerning registration of investment advisers to private funds and derivatives. On July 21, 2010, the President of the United States signed the Dodd-Frank Wall Street Reform and Consumer Protection $\mathrm{Act}^{2}$ into law. This revised report includes reference to that Act and supersedes the report appearing on the website for the IACL Congress. The general reporter's questionnaire is in an appendix to the United States report. For easy reference, short forms of some recurrent terms in the United States report appear in the following glossary.

\section{Glossary of Terms in this Report.}

"BHC" means Bank Holding Company Act.

"CEA" means the Commodities Exchange Act.

"CFIUS" means Committee on Foreign Investment in the United States.

"CFTC" means the Commodities Futures Trading Commission, the regulatory agency for commodities, swaps, and derivatives, other than security-based swaps and derivatives.

"Dodd-Frank" means the Dodd-Frank Wall Street Reform and Consumer Protection Act, Pub. Law 111-203 (July 21, 2010).

"Exchange Act" means the Securities Exchange Act of 1934.

"FINRA" means the Financial Industry Regulatory Authority, an SRO formed from consolidating the member regulatory function of the New York Stock Exchange and the National Association of Securities Dealers in 2007.

\footnotetext{
${ }^{1}$ AB Washington University, MA, JD The University of Chicago. Co-Director, Center for International and Comparative Law. The reporter thanks Ilene Ordower for her edit of the manuscript and Kim Hemenway, a Saint Louis University law student, for research assistance and preparation of the initial draft of the section on sovereign wealth funds.

${ }^{2}$ P.L. 111-203 (July 21, 2010) was H.R. 4173. The bill passed the Senate and was sent to the President on July 15, 2010. The President signed the legislation on July 21, 2010.
}

Regulation of Private Equity, Hedge Funds, and Sovereign Wealth Funds

United States of America Report

Professor Henry Ordower, Reporter

Saint Louis University School of Law

$18^{\text {th }}$ Congress, International Academy of Comparative Law 2010 
"FRB" means the Federal Reserve Bank.

"IAA" means the Investment Advisers Act of 1940, as amended.

"ICA" means the Investment Company Act of 1940, as amended.

"IMF" means International Monetary Fund.

"IRC" means the Internal Revenue Code of 1986, as amended, the United States federal tax laws.

"IRS" means the Internal Revenue Service, part of the United States Department of the Treasury that has primary administrative responsibility for interpretation and enforcement of the IRC.

"IWG" means International Working Group of SWFs.

"SEC" means the Securities Exchange Commission, a federal agency responsible for interpretation and enforcement of the securities laws of the United States, including the Exchange Act, the Securities Act, the ICA and the IAA.

"Securities Act" means the Securities Act of 1933, as amended.

"SRO" means a self-regulatory organization established under section 19 of the Exchange Act.

"SWF" means Sovereign Wealth Fund.

United States Reporter's Overview. $\underline{\underline{3}}$ In current usage in the United States, the concept of "hedge fund" is now reasonably settled. A hedge fund is a managed pool of capital that would be an "investment company," as ICA §3(a) defines that term, but for the limited number and wealth characteristics of the owners of the interests in the pool. ${ }^{4}$ The ICA regulates most aspects of investment companies' management and operation. Since hedge funds resemble but are not investment companies under the ICA, they are not subject to regulation under that statute. It is this absence of ICA regulation, and accompanying IAA regulation for the funds' investment advisers, ${ }^{5}$ that defines the hedge fund rather than any set of regulations applicable to the fund.

Following the recent worldwide downturn in the financial services industries, the retreat of the securities markets, and the massive investor losses from fraud in the form of

\footnotetext{
national report relies in part on that article.

${ }^{4}$ See discussion infra in text accompanying and following note 41 . investment adviser for advisers who must register under the IAA.

Regulation of Private Equity, Hedge Funds, and Sovereign Wealth Funds

United States of America Report

Professor Henry Ordower, Reporter

Saint Louis University School of Law

$18^{\text {th }}$ Congress, International Academy of Comparative Law 2010
}

${ }^{3}$ For a general explanation of U.S. managed hedge funds and their operations and structures, see Henry Ordower, Demystifying Hedge Funds: A Design Primer, 7 U. CAL. DAVIS Business L. J. 323 (2007). This

${ }^{5}$ This report uses the terms investment adviser and manager interchangeably. The IAA uses the term 
pyramid schemes, especially Bernard Madoff's pyramid scheme ${ }^{6}$ debate in legislatures and in the media has focused on new protections for investors and the integrity of the financial markets. Systemic risk, including counterparty risk in derivative products, like AIG's credit default swaps, and risk to investors from massive frauds have rallied legislators and commentators to re-examine the adequacy of existing regulation. A similar outcry for regulatory change followed the failure of Long Term Capital Management in $1999,{ }^{7}$ yet, as the markets recovered, no material regulatory change followed in the United States. On this occasion, however, Congress enacted Dodd-Frank and the President signed it into law. This new legislation addresses systemic risk by requiring clearing for many derivative products ${ }^{8}$ and registration for most investment advisors to hedge and private equity funds. ${ }^{9}$ It also includes a modicum of investor protection by requiring safeguarding and auditing of custodial funds. ${ }^{10}$ This report will address that debate and the new legislation in the context of additional regulation for pooled investments, like hedge and private equity funds, which now are only lightly regulated.

In order to gain insight into the function of hedge funds and private equity funds within the world of investment capital and investment products, I will contrast hedge funds with investment companies and distinguish them from similarly unregulated, private equity funds in terms of liquidity and investment strategies. The report will include a brief review of securities and investment company regulatory history in the United States to help place the discussion in perspective.

As a discrete part of the report, I will review the operation and legal treatment of sovereign wealth funds operating or investing in the United States. That discussion will concern itself with the possible mixing of political with investment objectives and the issue of whether or not to tax such funds.

A. Federal Securities and Investment Company Laws for Investor Protection not Systemic Risk. Following the crash of the United States markets in 1929, the United States Congress sought to prevent future market failures that injured so many investors. Congress settled on a strategy that relied on information disclosure. The strategy assumed that the market would assimilate the publicly disclosed information that the law would require and disseminate the analysis of the information to enable investors to make

\footnotetext{
${ }^{6}$ Ponzi scheme is the colloquial term for pyramid schemes like the one Bernard Madoff operated. The operator of a pyramid scheme uses funds contributed by new investors to pay a favorable return on investment to existing investors. So long as a constant inflow of new investment exceeds the withdrawals from the artificial investment pool, the scheme works. With the 2008 economic downturn, there were more requests for withdrawal from the Madoff investment funds than newly invested capital causing the scheme to collapse. Lack of transparency in private investment funds generally lends itself to such fraudulent schemes, as no independent governmental agency or SRO is monitoring the actual existence of the fund's investment positions.

${ }^{7}$ Discussed infra in text accompanying note 33.

${ }^{8}$ Titles VII and VIII of Dodd-Frank.

${ }^{9}$ Title IV of Dodd-Frank.

${ }^{10}$ Section 411 of Dodd-Frank adds section 223 to the IAA.
}

Regulation of Private Equity, Hedge Funds, and Sovereign Wealth Funds

United States of America Report

Professor Henry Ordower, Reporter

Saint Louis University School of Law

$18^{\text {th }}$ Congress, International Academy of Comparative Law 2010 
informed investment decisions. ${ }^{11}$ Some years later, Congress developed a more parental protection system for investors in investment funds. ${ }^{12}$

1. Disclosure and Investor Protection. The United States securities and investment company statutes focus on investor protection. The statutes rely primarily on disclosure to enable investors to control their investment risk by providing them the information necessary to evaluate a proposed investment with the help of market professionals. Professional participants in the market assimilate the publicly disclosed information and make professional and informed recommendations to investors. Sophisticated investors also may analyze the public information independently to determine whether or not they wish to make the proffered investment. ${ }^{13}$ In addition, SROs, including the national securities exchanges that are subject to regulation under the Exchange Act, have "know your customer" rules applicable to their broker/dealer participants. ${ }^{14}$ These "know your customer" rules should, but do not necessarily, prevent brokers and dealers from selling inappropriate securities to those customers. ${ }^{15}$ The "know your customer" rule requires each broker or dealer to evaluate the public information and determine whether the security is suitable for the broker's or dealer's customers before the broker or dealer makes a recommendation to the customer to buy the security. ${ }^{16}$

Unless an exception applicable to a security exists, the issuer of the security must register the security under section 5 of the Securities Act. The registration statement is a disclosure document and becomes publicly available. In addition, the Securities Act requires that the issuer provide each purchaser of the securities from the issuer or an underwriter a prospectus in advance of the sale of the securities to the investor. The prospectus must include all material information concerning the issuer and the securities. Information is material if the purchaser might find the information important in evaluating an opportunity to purchase the securities. In addition to financial information, the prospectus includes information concerning the issuer's business plan, proposed use of the proceeds from sale of the securities, and information about the issuer's market and its managers. There is little expectation, however, that the investor actually reads the prospectus. ${ }^{17}$ Rather the registration statement and prospectus place material information into the public domain where professional market participants, including brokers and dealers in securities, may assimilate the information and make informed recommendations to their customers with respect to the proposed investment and its

\footnotetext{
${ }^{11}$ The Securities Act and the Exchange Act.

12 The ICA and IAA.

${ }^{13}$ See additional discussion infra in text accompanying note 17.

${ }^{14}$ Exchange Act section 6.

${ }^{15}$ Recent manifestations of "know your customer" rules relate marginally to the historical securities law rules. Financial institutions currently must "know their customers" in the sense of whether those customers are laundering money or funding terrorist activities.

${ }^{16}$ While violation of the "know your customer" rule probably does not provide an independent claim for relief against a broker, although authorities are split on this issue, it may provide evidence of violation of the more general antifraud rules of the Exchange Act.

${ }^{17}$ Despite the statute, the delivery of the prospectus tends to lag the actual purchase of the securities.

Presumably the reversal of the order gives the purchaser a right of rescission. In view of the function of disclosure into the public domain and the market professionals' assimilation of the public information, the investor has the protection of the efficient capital market hypothesis despite delivery of the prospectus later.
}

Regulation of Private Equity, Hedge Funds, and Sovereign Wealth Funds

United States of America Report

Professor Henry Ordower, Reporter

Saint Louis University School of Law

$18^{\text {th }}$ Congress, International Academy of Comparative Law 2010 
suitability for those customers (subject to the constraints of the "know your customer" rule the previous paragraph discusses).

Following the sale of securities to the public, the Exchange Act regulates the market for information concerning issuers and resale of securities. Companies, the shares of which trade publicly, generally have an obligation to report their financial results annually or more frequently. In addition, each publicly traded company has an ongoing obligation to disseminate material information concerning its operations and management that might influence the value of its publicly traded securities, so that no one possessing the information may use it to his or her advantage in trading in the issuer's securities. Shareholders may not exploit an information advantage they may have because of their position in the company to buy or sell shares before the information becomes public. ${ }^{18}$

While the ICA relies on disclosure as well, it and the IAA intervene in substantive ways to control investor risk more directly than through disclosure. For example, the ICA prohibits investment advisers and promoters from engaging in transactions with the investment companies they promote or advise ${ }^{19}$ and requires investment companies to place and maintain their assets with independent banks or investment banks. ${ }^{20}$ Similarly, the SEC has promulgated a rule under the IAA that prohibits registered investment advisers or managers from retaining custody of the fund's assets. ${ }^{21}$ The ICA also imposes limitations on composition of the investment company's board of directors, ${ }^{22}$ requires an affirmative shareholders' vote for changes in investment policy, ${ }^{23}$ and prevents investment companies from selling short or employing substantial borrowing

\footnotetext{
${ }^{18}$ Section 10(b) of the Exchange Act and Rule 10b-5 that the SEC promulgated under that statute prohibit any form of market manipulation that results from an informational advantage. Rule 10b-5 reads:

It shall be unlawful for any person, directly or indirectly, by the use of any means or instrumentality of interstate commerce, or of the mails or of any facility of any national securities exchange,

(a) To employ any device, scheme, or artifice to defraud,

(b) To make any untrue statement of a material fact or to omit to state a material fact necessary in order to make the statements made, in the light of the circumstances under which they were made, not misleading, or

(c) To engage in any act, practice, or course of business which operates or would operate as a fraud or deceit upon any person, in connection with the purchase or sale of any security.
}

17 CFR 240.10b-5. See also Rule 10b5-1 applicable specifically to insider trading.

${ }^{19}$ ICA $\S 17(\mathrm{a})$.

${ }^{20}$ ICA $\S 17(\mathrm{f})$.

${ }^{21}$ Rule 206(4)-2 under IAA, 17 CFR 275.206(4)-2. Some commentators believe that the applicability of that custodial rule to Bernard Madoff's investment management activities would have prevented him from operating a Ponzi scheme, but Madoff may not have been acting as an investment manager at all. Rather Madoff's investors may have invested in his brokerage firm rather than any pooled fund. Custodial rules apply to investments in investment companies and not to investments in ownership of a brokerage firm. IAA section 233, as added by section 411 of Dodd-Frank, requires investment advisers to safeguard and audit funds under custody but does not separate the custodial from the advising functions as required for investment companies.

${ }^{22}$ ICA $\S 10$ (a) limits the interested board members to sixty percent of the board.

${ }^{23}$ ICA $\S 13$.

Regulation of Private Equity, Hedge Funds, and Sovereign Wealth Funds

United States of America Report

Professor Henry Ordower, Reporter

Saint Louis University School of Law

$18^{\text {th }}$ Congress, International Academy of Comparative Law 2010 
leverage ${ }^{24}$ essentially limiting investment companies to substantially conservative paid, long positions. The IAA imposes an array of requirements on registered investment advisers. Among the requirements, are some that seek to prevent unscrupulous individuals from becoming registered advisers. ${ }^{25}$ In addition, except in the case of qualified clients, the IAA restricts investment advisers from receiving performance fees that might cause their interests to conflict with those of their clients. ${ }^{26}$

While disclosure and the various investor protection measures under the ICA create a comprehensive, if somewhat narrow, system for investor protection, neither securities nor investment company regulation in the United States addressed systemic risk comprehensively even though systemic risk, for the moment, has become a grave, worldwide concern. To the extent that securities laws protect the integrity of the markets, that protection primarily is for the benefit of the investors in the issue of securities and not to prevent collateral injury to the enterprise itself, its employees, the community, or other enterprises. Collateral risks to non-investors have not been a matter for the SEC, as only investors who buy or sell securities have a claim under those statutes. Some statutory authority allows the SEC to intervene on a limited basis where systemic risk is present. For example, the SEC addresses systemic risk through its powers (i) to suspend trading in specific securities, (ii) to regulate industry participants, including brokers and dealers, and (iii) to impose various trading rules, such as the rule that outlawed the short selling of securities that were declining in value. ${ }^{27}$ Dodd-Frank focuses on systemic risk by requiring clearing of many derivative positions and recordkeeping for investment advisers to private funds.

As early as the 1980s, the state Supreme Court of Delaware began to address protection of constituencies other than shareholders in its corporate takeover decisions. ${ }^{28}$ Those decisions suggest that the corporate managers may resist a takeover attempt to protect the corporate existence, its culture, and its constituencies other than shareholders. ${ }^{29}$

2. Systemic Risk. Preoccupation with systemic risk is a relatively new phenomenon, although the Commodities Exchange Act has spoken more directly to systemic risk by seeking to control counterparty default risk. The trading of commodities futures contracts $^{30}$ under the Commodities Exchange Act is in standardized units and uses a fully

${ }^{24}$ ICA $\S \S 12$ and 18.

${ }^{25}$ IAA $\$ 203$.

${ }^{26}$ IAA \$205. This report discusses Rule 205-3 and qualified clients and result fees infra in text accompanying note 80 .

${ }^{27}$ Until July 2007, an SEC regulation allowed the sale of stock short only when the last trade had been an up tick in the stock price (or no change following an up tick). Exchange Act Rule 10a-1 (repealed July 5, 2007). Recently, the SEC proposed that it adopt a short selling restriction again in order to limit short selling in declining markets out of concern that short selling contributed to artificial acceleration of declines in market values recently. See Release No. 34-5974874, FR 18042 (April 20, 2009).

${ }^{28}$ Weinberger v. UOP, Inc., 457 A. 2d 701 (Del 1983). Delaware is the state of incorporation of the greatest number of publicly traded US corporations because its corporate laws favor management. ${ }^{29} \mathrm{Id}$.

${ }^{30}$ Futures contracts create a mutual obligation to deliver and accept delivery of and pay for a quantity of a commodity at a designated future time and at a contractually designated price. Despite that delivery requirement, futures contracts settle almost invariably in cash. As the value of the contract fluctuates with

Regulation of Private Equity, Hedge Funds, and Sovereign Wealth Funds

United States of America Report

Professor Henry Ordower, Reporter

Saint Louis University School of Law

$18^{\text {th }}$ Congress, International Academy of Comparative Law 2010 
hedged clearinghouse. The clearinghouse minimizes counterparty risk for investors by acting as the counterparty for all positions. The clearinghouse limits its own counterparty exposure by marking to market all positions at least daily and accompanying those marks with margin adjustments - both calls and releases of margin. Dodd-Frank has introduced a similar clearinghouse system for swaps and other derivative positions. Most swaps and other derivative products, whether subject to CFTC regulation or SEC regulation become subject to clearing and maintenance of margin in order to control systemic risk. ${ }^{31}$ In addition, new conflict of interest rules will control investor risk and limit parties offering derivative and swap contracts from investing in a manner that conflicts with their customers. $^{32}$ Similarly, as in the commodities markets, automatic suspensions of trading in the markets fend off possible panic reactions that might cause the market to collapse.

Historically, there was little, if any, discussion of the currently prevalent concern that some businesses might be too large or important to be permitted to fail because of their potential impact on the entire market. The collapse of Long Term Capital Management's hedge fund group in 1998-9 may have been the harbinger of that preoccupation. ${ }^{33}$ Long Term Capital Management was arbitraging very large positions in sovereign debt and utilizing vast amounts of leverage, so that a very small price movement would yield a greatly magnified gain or loss. When Russia suspended payments on its sovereign debt in mid-1998, investors sought to shift their debt positions to sovereign debt of G-7 issuers. Those shifts drove up the price of G-7 debt contrary to Long Term Capital Management's investments. While the United States government did not intervene with financial assistance to protect Long Term Capital Management or its investors, it did facilitate intervention by the membership of the New York Stock Exchange.

\section{B. Hedge Fund Background: Exemptions from Registration and Regulation, Structure, Taxation. This section describes common hedge fund structures and exemptions from registration requirements and accompanying regulation.}

1. Hedge Funds and Registration Exemptions. Without regard to the particular structure of the hedge fund, interests in the fund are securities for purposes of both the Securities Act and the Exchange Act. Since a manager, who may or may not own an interest in the fund, controls the fund's assets and investments, any investors' profit

and derives from the spot price for the underlying commodity, futures contracts are derivative contracts. Futures contracts govern physical commodities like grain and various commodities like indices that have no physical manifestation.

${ }^{31}$ Dodd-Frank section725, for example, establishes the registration of derivatives clearing organizations, and section 723 requires the clearing of swaps through one of the derivatives clearing organizations.

${ }^{32}$ Dodd-Frank section 732 and 765 requiting the CFTC and SEC to limit cross-ownership of clearing agencies to prevent conflicts of interest between parties that invest in derivatives and the clearing of derivatives.

${ }^{33}$ See, generally, Hedge Funds, Leverage, and the Lessons of Long-Term Capital Management - Report of the President's Working Group on Financial Markets, by representatives from the Commission, the Treasury Department, the Federal Reserve and the Commodity Futures Trading Commission (Apr. 1999) (examining market crisis that failure of LTCM precipitated). Note that in 1979-80, the federal government guaranteed loans for Chrysler Motor Company to protect the United States automobile industry and its collateral suppliers.

Regulation of Private Equity, Hedge Funds, and Sovereign Wealth Funds

United States of America Report

Professor Henry Ordower, Reporter

Saint Louis University School of Law

$18^{\text {th }}$ Congress, International Academy of Comparative Law 2010 
results from the efforts of others. ${ }^{34}$ The expectation that the investor will derive profit from the efforts of others is the principal identifying characteristic of a security.

While registration of securities is cumbersome and expensive, those concerns may not be the hedge fund promoter's chief reasons for avoiding registration. Hedge fund promoters eschew registration of interests in the funds to prevent the public dissemination of information concerning the fund -- its positions, strategies, and advisers -- since the registration statement is a public document. In some cases, registration jeopardizes incentive fees for hedge fund managers ${ }^{35}$ and fee generating custodial arrangements for the fund assets. ${ }^{36}$ Registration of the fund means registration as an investment company.

The Securities Act exempts from registration distributions of securities that do not involve a public offering. ${ }^{37}$ Industry participants refer to this no public offering concept as the private placement exemption. Underlying the private placement is the understanding that the investor does not require the protection that public disclosure of material information and market assimilation of that information provides. The statute does not define a private placement, but the courts and the SEC have grafted various rules and tests to distinguish public from private offerings of securities. ${ }^{38}$

Private placement implies that there will be no general advertising or sales solicitation of the offering. Identification of prospective purchasers depends upon the existence of some historical relationship between the issuer or one or more of its representatives and the prospective purchaser. The relationship enables the issuer to ascertain that the investor is a suitable prospect for the investment. In SEC v. Ralston Purina, ${ }^{39}$ the United States Supreme Court held that investors qualifying as purchasers of private placements must have (i) the wherewithal to bear the economic loss on failure of the investment, (ii) the sophistication, either themselves or with the assistance of their own advisers, to understand the investment and its risks, and (iii) access to the information that a registration statement would provide.

Despite the private placement exemption, the Exchange Act's general anti-fraud rules apply to interests in hedge funds. ${ }^{40}$ During the initial and continuing offering the issuer generally must provide private placement investors access to material information concerning the investment. Prospective investors should have an opportunity to ask questions of the issuer and its representatives and to receive satisfactory and complete answers to enable the potential investors to evaluate the investment and its risks. Most

\footnotetext{
${ }^{34}$ Securities Act $\$ 2(a)(1)$ defines "security" broadly. In addressing the question of interests in orange groves as investment contracts subject to the securities laws, the US Supreme Court approved these indicia of control and profit from the efforts of others. SEC v. W. J. Howey Co., 328 U.S. 293, 299 (1946).

${ }^{35}$ IAA $\$ 205(a)$. See discussion infra of exceptions for "qualified clients" that enable registered investment advisers to receive incentive fees under limited circumstances in text accompanying note 75. Rule 205-3 under the IAA.

${ }^{36}$ ICA $§ 17(f)$ and Rule 206(4)-2 under the IAA.

${ }^{37}$ Section 4(2) of the Securities Act.

${ }^{38}$ For the SEC's safe harbor rule, see Regulation D, Rules 501-508, under the Securities Act.

39346 U.S. 119 (U.S. 1953)

${ }^{40}$ See section 10(b) of the Exchange Act and Rule 10b-5 under that statute.
}

Regulation of Private Equity, Hedge Funds, and Sovereign Wealth Funds

United States of America Report

Professor Henry Ordower, Reporter

Saint Louis University School of Law

$18^{\text {th }}$ Congress, International Academy of Comparative Law 2010 
hedge funds provide their investors a disclosure document in the form of a private placement memorandum, which standardizes the disclosure and assures the issuer that it has made necessary disclosures. ${ }^{41}$

If hedge funds engage primarily in investing in or trading securities, they fall within the definition of investment company under section 3(a)(1)(A) of the ICA, so that, absent an exemption, hedge funds must register as investment companies. ${ }^{42}$ Until 1997, hedge funds relied on the 100 beneficial owner exemption under section 3(c)(1) of the ICA to avoid classification as investment companies. If the hedge fund did not have a public offering of its securities and limited the number of its owners to 100 persons, it was exempt from the investment company definition and the registration requirement. ${ }^{43}$ Since the United States securities laws protect only United States investors, both citizens and permanent residents, or activities that take place in the United States, non-resident alien investors and foreign entities did not count toward the 100 owner limitation.

Nevertheless, the 100 United States investor limitation proved to be problematic for raising capital, as a very large average investment was essential to provide the manager with a sufficient pool of capital to invest (or so the industry argued successfully to the United States Congress).

In 1997, the hedge fund industry captured additional investment slots when Congress added an exemption from the investment company definition for funds that only admitted very wealthy investors as owners. ${ }^{44}$ Funds that have as investors only "qualified purchasers" may have an unlimited number of owners. ${ }^{45}$ Qualified purchasers are investors who, in the case of individual investors, have at least $\$ 5$ million, net of debt, in investments exclusive of the hedge fund in question. ${ }^{46}$

The $\$ 5$ million minimum leaves the investor with significant capital even if the hedge fund investment becomes worthless. Rarely does a hedge fund, despite employing significant leverage in its investments, adopt an investment structure that allows the manager to make mandatory capital calls on the investors. ${ }^{47}$ Only the investment that the investor makes or pledges to the fund is at risk for the investor, while the promoter, as

\footnotetext{
${ }^{41}$ Attorneys tend to prepare the private placement memoranda with the assistance of their fund promoter clients. Stylistically, the memoranda disclose material information in prose that often is difficult to read and understand.

${ }^{42}$ Some hedge funds may invest only in derivative products that are not securities or commodities and free from regulation in the US. While I am unaware of any fund that has relied on investment solely in derivative products to avoid classification as an investment company, avoidance of the classification in this manner was theoretically possible until enactment of Dodd-Frank which classifies derivatives as either commodities or securities for regulatory purposes.

${ }^{43}$ The practical limitation was 99 as most hedge funds were limited partnerships with the promoter as the general partner occupying one of the beneficial ownership slots.

${ }^{44} \mathrm{ICA} \S 3(\mathrm{c})(7)$.

${ }^{45}$ Exchange Act $\$ 12(\mathrm{~g})$ requires issuers to register and file periodic reports if they have 500 or more shareholders. In order to avoid registration under the Exchange Act, qualified purchaser funds under ICA $\S 3(c)(7)$ must limit their investor number to 498 leaving one slot for the general partner of the hedge fund partnership.

${ }^{46}$ ICA $\S 2(a)(51)$.

${ }^{47}$ On the other hand, private equity funds may have capital calls.
}

Regulation of Private Equity, Hedge Funds, and Sovereign Wealth Funds

United States of America Report

Professor Henry Ordower, Reporter

Saint Louis University School of Law

$18^{\text {th }}$ Congress, International Academy of Comparative Law 2010 
general partner, the lenders, and the fund's derivative position counterparties bear the underlying risk from leverage. If lenders and derivative position counterparties are too open-handed in their extensions of credit to hedge funds, failure of the hedge funds, as was the case with Long Term Capital Management and, more recently, AIG on its credit default swaps, put the lenders and derivative counterparties in financial jeopardy.

By contrast, Lloyds of London utilized an unlimited investment risk model for its investors. Investors in Lloyd's insurance pools - referred to as "names" -- received a relatively high return on their invested capital. If, however, the funds in the insurance pool proved inadequate to pay claims against the pool, Lloyds could call upon its pool names to pay the claims without limitation. While historically Lloyds' business model was extremely successful and the mystique of becoming a Lloyds' name was evidence of one's status, many Lloyds' names risked losing their fortunes when some insurance risks proved less benign than people had thought. ${ }^{48}$ Environment hazards that Lloyds insured, such as asbestos, placed names at great economic risk and spurred substantial litigation against Lloyds under antifraud provisions of the United States and state securities laws. ${ }^{49}$

Management and Taxation Considerations. Until 1997, United States -based hedge fund promoters generally located their funds and the management activities of those funds offshore. Preferred jurisdictions included the Cayman Islands, the British Virgin Islands, and Bermuda. ${ }^{50}$ An offshore base was critical to prevent the funds' trading income from becoming United States source income. ${ }^{51}$ Since the fund entities were foreign corporations for United States tax purposes and engaged in much of their trading activity for their own account in United States markets, the income remained non-United States source income only as long as the funds' principal office was not in the United States. Holding meetings and conducting other activities in the offshore jurisdiction were critical to determination of the location of the funds' principal office. ${ }^{52}$ The island jurisdictions offered minimal, if any, taxation, little regulatory oversight (Bermuda possibly being the exception), English as a primary language, and easy access by air from New York City for the managers and directors to hold meetings and oversee the necessary offshore functions.

\footnotetext{
${ }^{48}$ For a theatrical description of the Lloyds' business model, see David Hare, Amy's View, Act 3 where Esme describes her visit to Lloyds in terms of the wood paneled conference room and the real china tea service. She says nothing about disclosures or her understanding of any risks in the investment that ultimately causes the loss of most of her capital.

${ }^{49}$ See, for example, the litigation website at http://www.uniset.ca/lloyds_cases/lloyds_cases.html.

${ }^{50}$ Under the OECD harmful tax competition standard, the principal jurisdictions are tax havens. HARMFUL TAX COMPETITION: AN EMERGING GLOBAL ISSUE (OECD, 1998).

${ }^{51}$ IRC $\$ 864(\mathrm{~b})(2)$ provides a special rule that sources income for foreign individuals and corporations from trading securities and commodities for their own account outside the U.S. However, until an amendment in 1997, that statute would have treated the trading income as U.S. source if the corporation's principal office were in the U.S.

${ }^{52}$ Treas. reg. $\$ 1.864-2(\mathrm{c})(\mathrm{iii})$ set forth ten functions of a principal office and classified the office as U.S. or non-U.S. based upon where most of those functions took place. Industry participants colloquially referred to those functions as the "ten commandments."
}

Regulation of Private Equity, Hedge Funds, and Sovereign Wealth Funds

United States of America Report

Professor Henry Ordower, Reporter

Saint Louis University School of Law

$18^{\text {th }}$ Congress, International Academy of Comparative Law 2010 
Whether those promoters chose their fund locations originally to facilitate tax avoidance for their United States investors is doubtful. ${ }^{53}$ While a small number of United States investors may have sought to hide their hedge fund income from United States taxation, ${ }^{54}$ the passive foreign investment company (PFIC) rules made that decision a risky choice. ${ }^{55}$ Many investors subject to United States taxation preferred to make the election available under the PFIC rules to include their shares of the income of the foreign corporation annually, rather than subjecting their eventual gain to the unfavorable PFIC tax regime. ${ }^{56}$ Obviously, those seeking to hide income could not make the election.

After the Department of the Treasury adopted the so-called "check-the-box" rule for entity classification in $1997,{ }^{57}$ many managers chose to have the foreign investment funds with United States taxable investors elect partnership status for tax purposes. Under United States tax law, partnerships are transparent for tax purposes; the entity pays no tax, but its owners include their shares of the partnership's tax items - income, loss, deduction, and credit - in their separate tax computations as if the partner received that share from the same source and in the same manner as the partnership did. ${ }^{58}$ Each investor receives a statement annually from the fund that shows the investor's share of the fund's tax items ${ }^{59}$ and reports that share on the investor's United States federal income tax return.

\footnotetext{
${ }^{53}$ Recent disclosures show that numerous high net worth U.S. individuals secreted substantial funds in Swiss bank accounts. David Voreacos and Carlyn Kolker, UBS Clients Await Details of U.S. -Swiss Pact on Secret Accounts, (http://www.bloomberg.com/apps/news?pid=20601102\&sid=a9aCm.G382EA). As their funds were already secretly offshore, those individuals would not need the assistance of hedge funds to evade U.S. taxes. See, generally, Henry Ordower, The Culture of Tax Avoidance, 55 SAINT LOUIS U. L. J. (2010 forthcoming).

${ }^{54}$ U.S. citizens and permanent residents are subject to U.S. income tax on their worldwide income from all sources. IRC §61. To the extent that the income becomes subject to tax in another jurisdiction, the U.S. generally grants a credit or a deduction for the foreign tax the taxpayer pays. IRC $\$ 901$ provides for the foreign tax credit.

${ }^{55}$ IRC $\$ 1291$ et seq. defines investment, as opposed to operating, foreign corporations as PFICs and imposes a tax on distributions and gain from the sale of interests in the foreign corporation attributable to years other than the year of distribution or sale under the PFIC rules at the maximum rate under U.S. law and an interest charge on the deferral over the period during which the investor held an interest in the foreign corporation. Accordingly, some of the income of the foreign corporation that might have been long term capital gain if the U.S. investors had earned it directly would become ordinary income to the investors under the PFIC regime. Long term capital gain currently is subject to a maximum rate of tax to U.S. individuals of 15 percent while ordinary income is subject to a maximum rate of 35 percent.

${ }^{56}$ IRC $\$ 1295$ provides investors in PFICs with a qualified electing fund election that permits them to preserve the character of the fund's income, long term capital gain or ordinary income, with the current inclusion of the income under IRC $\$ 1293$. Investors may defer inclusion by agreeing to pay interest on the deferred tax amount.

${ }^{57}$ Treas. reg. $\$ 301.7701-3$ permits many foreign entities to elect classification as partnerships for U.S. tax purposes. Because of some opportunities to game the U.S. foreign tax credit rules, the "check-the-box" election currently is under siege. President Obama's tax reform proposals include repeal of the election. U.S. Department of the Treasury, General Explanations of the Administration's Fiscal Year 2010 Revenue Proposals 28 (May 11, 2009)(the "green book"). See Lee Sheppard, Check-the-Box Repeal Likely to be Enacted, 124 TAX NOTES 116 (July 13, 2009).

${ }^{58}$ IRC $\$ 701$ et seq.

${ }^{59}$ For U.S. partnerships, the statement is a K-1 statement. Since the foreign entity is not subject to U.S. taxing jurisdiction, it need not file a U.S. tax return, but it makes the necessary computations and reports to the investors on substitute K-1 forms.
}

Regulation of Private Equity, Hedge Funds, and Sovereign Wealth Funds

United States of America Report

Professor Henry Ordower, Reporter

Saint Louis University School of Law

$18^{\text {th }}$ Congress, International Academy of Comparative Law 2010 
However, the 1997 change in the principal office rule for sourcing income from securities trading obviated the need for United States managers to maintain extensive facilities and operations outside the United States. ${ }^{60}$ With the statutory change, a United States principal office would no longer cause securities trading income to have a United States source if foreign investors or foreign funds received the income. Operational shift to the United States without jeopardizing the foreign source for the income that foreign investors received led to an increasing use of United States limited partnerships for hedge funds. The change facilitated the migration of many offshore funds with United States taxable investors to the United States and enabled hedge fund promoters to adopt the now common master-feeder structures for the hedge fund family. United States investors would become limited partners in tax transparent, United States hedge fund limited partnerships. The partnerships would admit only United States qualified purchaser investors, ${ }^{61}$ one or more offshore corporate funds, and possibly a United States partnership fund limited to 100 investors for non-qualified purchasers. ${ }^{62}$ Since the United States taxable investors would invest in the United States limited partnership, the offshore funds no longer needed to elect United States partnership status. Those funds that invested in the partnership would not be engaged in a trade or business in the United States because of the source exemption for trading for one's own account. ${ }^{63}$ The offshore fund could admit non-United States investors without limitation free from constraints of the securities and investment company laws of the United States.

Since the offshore fund was not tax transparent for United States tax purposes, it (or a separate non-tax transparent offshore fund) would accommodate tax exempt United States investors, including retirement plans. ${ }^{64}$ If tax exempt United States investors joined the United States partnership directly, they would be likely to become subject to the unrelated business income tax. ${ }^{65}$ Since most hedge funds use borrowing leverage, hedge fund income in part is debt financed income. A tax exempt investor's share of that income would be debt financed and, therefore, subject to the unrelated business income tax. ${ }^{66}$ Absent tax transparency, however, the tax exempt investor derived gain from appreciation in the value of its interest in the offshore fund and not from the fund's income. That appreciation was not debt financed even though the underlying income, if received as a share of a partnership's income, would be unrelated business income to the tax exempt investor. ${ }^{67}$

\footnotetext{
${ }^{60}$ IRC $\$ 864(\mathrm{~b})$. Among the arguments for the change in the sourcing rule was that maintenance of an offshore office resulted in loss of revenue to the U.S. without creating any kind of useful barrier to the creation and management of the funds.

${ }^{61}$ ICA $§ 2(a)(51)$ investors with at least $\$ 5$ million of investments. ICA 3(c)(7) funds.

${ }^{62} \mathrm{ICA} \$ 3(\mathrm{c})(1)$.

${ }^{63}$ IRC $\$ 864(b)(2)$. This is a critical link in the U.S. tax rules because the general partnership rule is that a partner's share of the partnership's income retains the character in the partner's hands that it would have in the partnership's hands. Thus partners in U.S. partnerships, whether general partners or limited partners, are engaged in the trade or business of the partnership.

${ }^{64}$ A U.S. corporation would work as well for tax exempt investors, but a U.S. corporate fund itself would be subject to U.S. income tax.

${ }^{65}$ IRC $\$ 511$.

${ }^{66}$ IRC $\$ 514$

${ }^{67}$ IRC $\$ 702(b)$
}

Regulation of Private Equity, Hedge Funds, and Sovereign Wealth Funds

United States of America Report

Professor Henry Ordower, Reporter

Saint Louis University School of Law

$18^{\text {th }}$ Congress, International Academy of Comparative Law 2010 
The needs of United States tax exempt investors and foreign investors wishing to remain free from United States regulatory oversight and taxation and possibly taxation in their home jurisdictions required the continued use of offshore funds. Offshore funds also enabled United States managers to capture a tax deferral benefit on their own compensation by using rabbi trusts with the offshore hedge funds. ${ }^{68}$ To the extent that the hedge fund transferred the manager's fees to a trust that remained subject to the claims of the fund's creditors, ${ }^{69}$ the compensation was not taxable to the manager until withdrawn from the trust. ${ }^{70}$ The fund would transfer the manager's incentive fees that were 10-20 percent of the increase in the value of the fund's assets rather than the asset based fees that were one to two percent of the assets in the fund. The fund could claim no deduction for the compensation until the manager included it in income, but the foreign and tax exempt investors were indifferent to the deduction, as they were not taxable in the United States. At the same time, the deduction was not valuable to the fund itself, as its income was taxable in a low or no tax jurisdiction. In 2006, Congress sought to curtail this practice by requiring current inclusion of such deferred compensation in the manager's income. ${ }^{71}$ The deferral of compensation income was not without risk if the fund's liabilities gave the fund's creditors a claim to the trust's assets. Careful drafting of the terms of the trust could minimize, but not eliminate, the risk.

Hedge fund promoters preferred United States limited partnerships to limited liability companies, even though limited liability companies are partnerships for United States tax purposes. ${ }^{72}$ The limited partnership offered the manager unfettered management control without interference from the limited partners. Even manager-managed limited liability companies may have members who are active in the conduct of a business and are somewhat more vulnerable to intervention from investors than are limited partnerships. ${ }^{73}$ With a limited partnership, it was simple for the manager to take its incentive fee as a partnership profit interest that might yield long term capital gain rather than ordinary compensation income. ${ }^{74}$

\footnotetext{
${ }^{68}$ Henry Ordower, A Theorem for Compensation Deferral: Doubling Your Blessings By Taking Your Rabbi Abroad, 47 THE TAX LAWYER 301 (1994) (suggesting the use of offshore rabbi trusts and analyzing their economics with present value analysis). Compare this deferral structure with the opportunity to receive compensation as long term capital gain discussed in the text accompanying note 74 infra.

${ }^{69}$ A so-called "rabbi" trust as it was a Jewish congregation that first established such a trust for deferred compensation for its rabbi.

${ }^{70}$ Under IRC 83, there was no taxable transfer while the trust's assets remained subject to the claims of the hedge fund's creditors.

${ }^{71}$ IRC $\$ 409 A(b)$.

${ }^{72}$ Under treas. reg. $\$ 301.7701-2(c)(1)$, the default classification for limited liability companies with more than one member is partnership for tax purposes.

${ }^{73}$ In fact, while a limited partner's interest in an operating, as opposed to an investment, partnership generates passive activity income and loss for purposes of the passive activity loss limitations under IRC $\S 469(\mathrm{~h})(2)$, a member's interest in a limited liability company does not necessary generate passive activity income and loss when the member materially participates in conducting a business as the cases of Garnett v. Commissioner, 132 T.C. No. 19 (June 30, 2009) and Thompson v. United States, No. 06-211 T (Fed Cl. July 20, 2009), recently held.

${ }^{74}$ Rev. Proc. 93-27, 1993-2 C.B. 343 (treating the receipt of a profits interest for services as non-taxable when received, unless certain exceptions rendering valuation simple and straightforward apply, leaving the partner to receive a distributive share of the partnership's income). IRC §702(b). There is extensive current
}

Regulation of Private Equity, Hedge Funds, and Sovereign Wealth Funds

United States of America Report

Professor Henry Ordower, Reporter

Saint Louis University School of Law

$18^{\text {th }}$ Congress, International Academy of Comparative Law 2010 
C. Registered Hedge Funds. Investment advisers to investment companies must register under the IAA ${ }^{75}$ and, generally, may not receive any portion of the investment company's gains or capital appreciation as a fee. ${ }^{76}$ This incentive fee prohibition does not apply to investment advisers who or which are exempt from registration under the IAA. ${ }^{77}$ As hedge fund advisers normally receive a result fee of ten to twenty percent of the fund's capital appreciation, either as a fee or as a profit participation, ${ }^{78}$ registration would be costly to successful managers if it resulted in losing their incentive fees. SEC rules promulgated first in 1985, and later amended, permit registered advisers to unregistered qualified purchaser investment funds ${ }^{79}$ and to "qualified clients" to receive an incentive fee. ${ }^{80}$ Investment advisers may contract to charge incentive fees to investors in registered investment companies with qualified clients, as long as any unqualified client investor does not pay an incentive fee. These "qualified client" investment companies largely take the form of hedge funds that invested in other hedge funds, so-

discussion of whether or not to alter U.S. tax rules to treat those profits interests that participants in the industry refer to as "carried interests" as ordinary income rather than as a share of the partnership's profit having the same character as the income has to the partnership - possibly long term capital gain. Current tax reform proposals would classify the income from carried interests as ordinary income. The green book, supra note 57 at 23 . The most recent proposing pending, but currently stalled, in the U.S. Congress is the American Jobs and Closing Tax Loopholes Act of 2010, H.R. 4213 (last action June 22, 2010), would add section 710 to the IRC and tax all or part of income from the carried interest as ordinary rather than capital for investment service partnerships. See, generally on the issue of service partnerships, Henry Ordower, Taxing Service Partners to Achieve Horizontal Equity, 46 The Tax Lawyer 19 (1992) (arguing that the profits interests should be taxable as open transactions) and Victor Fleischer, Two and Twenty: Taxing Partnership Profits in Private Equity Funds, 83 N.Y.U.L. REV. 1 (2008) (analyzing various arguments for taxing a profits interest but concluding that the private equity fund managers should have ordinary income from their profits interests in the private equity funds). The long term capital gain/compensation issue affects private equity fund managers somewhat more than hedge fund managers because much hedge fund income is ordinary income or short term capital gain, taxed under U.S. law as ordinary income to the extent that it does not offset long or short term capital loss. Some hedge funds trade commodities yielding gain and loss that is 60 percent long term and 40 percent short term capital under IRC $\S 1256$. Private equity funds often sell large positions in a single corporation that the fund has held for more than a year thereby yielding substantial long term capital gain.

${ }^{75}$ IAA $\S 203(b)(3)$.

${ }^{76}$ IAA $\$ 205(\mathrm{a})$.

${ }^{77}$ Hedge fund advisers generally rely on the registration exemption under IAA §203(b)(3) for advisers having fewer than fifteen clients. In 2006, the SEC sought, albeit unsuccessfully, to extend mandatory registration under the IAA to many hedge fund managers. IAA Rule 203(b)(3)-2 (invalidated and withdrawn). In Goldstein v. SEC, 451 F.3d 873 (D.C. Cir. 2006), the Court of Appeals for the D.C. Circuit invalidated the new regulations following the date on which managers first had to register under the regulations. The revised regulations would have altered the manner in which an investment advisor counts clients. Managers who previously did not have to register because they had fewer than fifteen clients would have had to count each investor in a hedge fund — rather than only the fund itself — as a client for purposes of the fewer than fifteen client rule. Ordower, Demystifying Hedge Funds, supra, note 3 at 4.

${ }_{78}^{78}$ See discussion of the profit participation supra in note 74 and accompanying text.

${ }^{79}$ Funds exempt under ICA $\S 3(\mathrm{c})(7)$.

${ }^{80}$ IAA Rule 205-3. Registered investment advisers may charge incentive or result fees to "qualified clients" who, in the case of individuals, have at least $\$ 1.5$ million in assets under the current rule, as opposed to the \$1 million asset threshold for "accredited investors" to whom issuers may sell private placement securities with no limit on the number of offerees or investors. See Securities Act Reg. D and Rule 501.

Regulation of Private Equity, Hedge Funds, and Sovereign Wealth Funds

United States of America Report

Professor Henry Ordower, Reporter

Saint Louis University School of Law

$18^{\text {th }}$ Congress, International Academy of Comparative Law 2010 
called "funds of funds." By investing in other hedge funds, the registered company does not run afoul of limitations under the ICA on use of financial leverage or short selling, as those activities would occur only at the level of the funds in which the registered fund invested and not in the registered fund itself.

This retail product of a registered fund of funds emerged when the SEC permitted the incentive fees in 1985 but did not capture any significant portion of the investment company market until later. While I am certain that the number of registered funds of hedge funds grew steadily after 1998, published statistics do not track those funds separately. ${ }^{81}$ A recent government study estimates that there are 1991 registered hedge fund advisers. ${ }^{82}$ That number of registered advisers will grow materially under DoddFrank which eliminates the exemption from registration for most advisers to hedge funds. ${ }^{83}$ Registration will not affect the advisers' ability to collect incentive fees.

D. Private Equity Funds Contrasted with Hedge Funds. Hedge funds and private equity funds often resemble one another structurally. As hedge fund managers employ a broad range of investment strategies, it is difficult to generalize a description of hedge fund investing. Hedge funds tend to trade actively, taking both long and short positions. Hedge funds invest in a diverse portfolio of securities, derivative positions, and, sometimes, commodities, and seek to maintain relative liquidity so that their investors may invest and disinvest at regular intervals ranging from monthly to annually.

Illiquidity hinders disinvestment at times, and hedge funds need to create a "side-pocket" for illiquid positions, so that investors wishing to disinvest may redeem the bulk of their investment but continue to own an interest in the side-pocket until the fund ultimately disposes of the illiquid positions. Hedge funds only occasionally acquire a sufficiently large position to control a company although they may acquire a large position with the intention of influencing management in order to affect the short term share price and value of the investment. Influence is not generally the primary objective and hedge funds may risk violating the antifraud rules of the Exchange Act if their influence constitutes share price manipulation.

Private equity funds focus their portfolios on one or a few positions for a long term investment strategy often with the objective to acquire control of their investment targets in order to capture management. The funds seek to increase the value of the target, possibly only short term, so that the target will have sufficient resources to pay the private equity fund's acquisition indebtedness and provide a substantial return to the private equity fund investor over a two to five year period.

Once in control, private equity funds tend to alter the structure of their targets by disposing of assets that the targets do not deploy efficiently and replacing or restructuring management and the target's business plan to enhance value - at least in the short term.

\footnotetext{
${ }^{81}$ See, for example, Investment Company Institute, 2009 INVESTMENT COMPANY FACTBOOK, available at http://www.icifactbook.org/index.html.

${ }^{82}$ GAO 09-677T, Hedge Funds: Overview of Regulatory Oversight, Counterparty Risks, and Investment Challenges (Statement of Orice M. Williams, Director, Financial Markets and Community Investment) 7 (May 7, 2009).

${ }^{83}$ Section 403 of Dodd-Frank.
}

Regulation of Private Equity, Hedge Funds, and Sovereign Wealth Funds

United States of America Report

Professor Henry Ordower, Reporter

Saint Louis University School of Law

$18^{\text {th }}$ Congress, International Academy of Comparative Law 2010 
At the end of the two to five year period investment window, the private equity fund either will resell the target or syndicate it in a public offering of shares. The fund then returns its capital to its investors, or, alternatively, invests in another target enterprise allowing investors who prefer to withdraw their investment in the fund. Accordingly, private equity fund investments are illiquid, with investors committing their capital for the full investment window. ${ }^{84}$ Occasionally, the private equity funds will make provision for capital calls on the investors, or, alternatively, provide the investors the opportunity to invest further capital as needed in preference to new investors. If the fund has capital calls, there is a ceiling amount that the investor must contribute to the fund. An openended commitment like the Lloyds of London model for its names would be exceptional.

The fund adviser uses the same fee structure as a hedge fund adviser - as a general guideline, two percent annually of the fund's assets and twenty percent of the increase in the fund's value. Private equity funds lend themselves to incentive fees in the form of partnership profits interests in the private equity fund limited partnership, since the receipt of the interest itself is not taxable under current law. The partner's share of the profits occurs as long term capital gain from the investment at the end of the investment life. Under current law, the IRC taxes those profits as long term capital gain at a maximum rate of fifteen percent for individuals, rather than the maximum rate for ordinary income, including compensation, of thirty-five percent for individuals. ${ }^{85}$

Private equity funds play a variety of roles in the market. Some acquire failing closely held businesses at low prices, often with seller financing, and seek to restructure them to make them profitable. Others resemble venture capital funds; they acquire interests in nascent businesses with promising managers. Most visible, however has been private equity funds' involvement in major corporate takeovers, both friendly and hostile.

In the public arena, tender offers provide the basic structure for corporate takeovers. If the private equity fund wants to take the target corporation private, eliminating public shareholders and accompanying reporting requirements under the Exchange Act, the takeover assumes the shape of a two step acquisition. The first step is a tender offer for a controlling or greater percentage of the shares of the publicly-traded target corporation. The second step is a merger or short form merger of the target with an acquisition corporation to eliminate the minority shareholders who did not tender their shares or whose shares the tender offeror did not acquire.

The Exchange Act imposes a series of disclosure and procedural requirements on tender offers to protect shareholders and prevent the tender offeror from gaining an unfair advantage over the current management. ${ }^{86}$ The private equity fund may not circumvent the tender offer rules with market purchases of shares. It may obtain no more than a five

\footnotetext{
${ }^{84}$ Despite commitments, many private equity fund managers will purchase or arrange the purchase of the interest of an investor who wishes to withdraw from the investment pool.

${ }^{85}$ See discussion supra in text accompanying note 74 and proposals to tax the manager's share of the profit as ordinary income. The ordinary income rate reverts to 200139.6 percent for individuals after 2010 under the sunset provision in 2001 taxation legislation.

${ }^{86}$ Exchange Act $§ 14(d)$.
}

Regulation of Private Equity, Hedge Funds, and Sovereign Wealth Funds

United States of America Report

Professor Henry Ordower, Reporter

Saint Louis University School of Law

$18^{\text {th }}$ Congress, International Academy of Comparative Law 2010 
percent interest in the target before it must make public disclosure of its intentions. ${ }^{87}$ Various rules prevent the tender offeror from pressuring shareholders to accept an offer before the shareholders have had an opportunity to observe the market reaction to the offer or management has had an opportunity to respond to the offer. For example, a tender offer must remain open for twenty days during which shareholders who have tendered their shares may withdraw their tenders in favor of a competing tender offer or for any other reason. ${ }^{88}$ If the offeror increases the price paid for shares, the offeror must pay the increased price to earlier tendering shareholders. ${ }^{89}$ And tender offers for less than all shares of the target must be pro rata to all tendering shareholders. ${ }^{90}$

Target corporations' managers have utilized a broad range of defensive tactics to ward off the potential private equity fund suitor for control of the corporation. Target corporations have identified other potential bidders for the corporation and offered favorable terms for purchase of the target's best assets if the favored bidder's offer is unsuccessful. ${ }^{91}$ Sometimes targets make cash distributions to shareholders and even incur debt to make distributions, since most private equity funds borrow substantial sums to buy the target's shares and then use the target's liquid assets to repay the acquisition indebtedness. A target with a great deal of debt or little cash is unattractive.

Considerable litigation has ensued from takeover attempts and corporate resistance to potential takeovers. Most litigation has been in Delaware state courts because Delaware is the state of incorporation for many public companies and questions of permissible takeover defenses and management's fiduciary duties are matters of state, not federal law. $^{92}$

After the acquisition private equity funds take an active role in the conduct and restructuring of the corporate business. Since most takeovers use leveraged buyout techniques that impose the acquisition indebtedness on the target corporation, the takeovers tend to put the target at risk by materially increasing its debt-equity ratio. When the target enterprise has been unproductive, the private equity fund might sell the target's component businesses separately, destroying the target as a continuing venture where that makes the greatest economic sense. However, if economic maximization for the owner has an adverse impact on employees and the community, consideration of those constituencies might require the continued operation of the economically inefficient business. The Delaware Supreme Court has been receptive to arguments that management may use corporate resources to defend against a hostile takeover to preserve the enterprise. Once management has concluded that the corporation will change

\footnotetext{
${ }^{87}$ Exchange Act $\$ 13(\mathrm{e})$.

${ }^{88}$ Exchange Act Rule 14e-1.

${ }^{89}$ Exchange Act $\$ 14(d)(7)$.

${ }^{90}$ Exchange Act $\$ 14(\mathrm{~d})(6)$.

${ }^{91}$ American takeover practice has developed a colorful vocabulary for takeover fights. The favored bidder is a "white knight," the target's best assets, the "crown jewels" and so forth.

${ }^{92}$ Santa Fe Industries v. Green, 430 US 462 (1977) (holding that there is no federal securities law claim for claims under corporate law). The cases of Unocal Corporation v. Mesa Petroleum Co., 493 A.2d 946 (Del 1985), Moran v. Household International, Inc., 500 A. 2 d 1346 (Del 1985), and Revlon v. MacAndrews \& Forbes Holdings, Inc., 506 A. 2d 173 (Del 1985), all involve takeover fights and questions of permissible defenses.
}

Regulation of Private Equity, Hedge Funds, and Sovereign Wealth Funds

United States of America Report

Professor Henry Ordower, Reporter

Saint Louis University School of Law

$18^{\text {th }}$ Congress, International Academy of Comparative Law 2010 
ownership, it may seek only to maximize the sale price for shareholders. Management no longer may rely on arguments of protecting the corporate enterprise or other constituencies as justifications for favoring one bidder over another. ${ }^{93}$

E. Enhanced Regulation: Categorizing and Controlling Risks. For legislators and regulators who view hedge or private equity funds as significant contributors to the collapse of the markets in 2008, the question is one of which risks governmental intervention and regulation should address. The preceding discussion identifies at least four different categories of parties subject to risk from the activities of hedge and private equity funds. Each category of parties is subject to multiple risk types - some specific to the funds, other more general market risks. Diminution and management of each risk type may require a regulatory configuration different from each other risk type. Among the parties subject to risk: (1) investors in the fund itself, (2) investor participants in the markets in which the fund is active but not investing in the fund, (3) parties doing business with the fund directly, including lenders and derivative counterparties, and (4) enterprises, including workers, and communities, that become the takeover targets of private equity funds or in which hedge funds acquire large positions. Further there is the fundamental systemic risk that the activities of the fund might increase.

\section{Fund Investor Risk.}

a. Investor Characteristics. Assuming that the bulk of investors in hedge and private equity funds meet the qualified purchaser test, risk to fund investors is not compelling as a premise for increased regulation under the disclosure/investor-protection underpinnings of the securities laws. In comparison with open-ended financial risk under a business model like Lloyds of London, ${ }^{94}$ the conclusion that hedge or private equity fund investors need the protections that registration would provide them seems misplaced. The sum that the investor agrees to invest defines the investor's exposure, and a wealthy investor generally makes investments with differing risk/reward profiles, so a loss of the invested amount is consistent with the investor's investment goals. Even when an investor suspects that managers are engaging in illegal or unethical trading and management practices ${ }^{95}$ and the investor may have a private cause of action under the securities law, most investors prefer to withdraw from the fund quietly.

As hedge funds have become retail investment products for investors who have only moderate assets, ${ }^{96}$ it makes sense to treat hedge funds as other retail products and have registration and additional regulation under the Securities Act and ICA. One regulatory concern might be that promoters or broker/dealers are selling hedge and private equity fund investments to investors who cannot tolerate the economic risk or require greater liquidity than either type of fund provides. The two to five year lock-up in private equity funds is appropriate only for investors not requiring investment liquidity. While hedge funds, unlike private equity funds, do not lock investors in for extended periods, they

\footnotetext{
${ }^{93}$ Revlon v. MacAndrews \& Forbes Holdings, Inc., 506 A. 2d 173, 182 (Del 1985).

${ }^{94}$ This report describes the Lloyds' business model supra in text accompanying note 49.

${ }^{95}$ See discussion infra in text accompanying note 106.

${ }^{96}$ See discussion supra in text accompanying note 75.
}

Regulation of Private Equity, Hedge Funds, and Sovereign Wealth Funds

United States of America Report

Professor Henry Ordower, Reporter

Saint Louis University School of Law

$18^{\text {th }}$ Congress, International Academy of Comparative Law 2010 
nevertheless may be too illiquid for investors who need the ready access to their money that mutual funds generally provide. Hedge funds tend to allow redemptions at thirty to ninety day intervals but frequently require a lengthy advance notice of the investor's intention to redeem. Some of the rules are in place already. If investment marketers sell to inappropriate investors, they violate the "know your customer" rules that SROs impose upon market participants.

Congress and the SEC, in exercising its rulemaking authority, have dealt with different levels of investor protection providing the least protection for qualified purchasers, greater protection for moderately wealthy investors who have at least $\$ 1.5$ in assets, ${ }^{97}$ and, finally, full investment company status and protections, including a prohibition on incentive fees, for funds that may offer and sell their interests publicly without regard to the characteristics of the investor. ${ }^{98}$ With or without registration, interests in all funds are securities subject to the antifraud provisions of the Exchange Act, so failures of disclosure give the investor a private right of action and permit the SEC to initiate enforcement proceedings. ${ }^{99}$ In addition, specific prohibitions apply to investment advisers engaging in manipulative practices. ${ }^{100}$

b. Conflicts between Investors' and Managers' Interests. Unregistered funds are subject to additional investment risks. Registered investment companies must mark positions for which market quotations exist to their current market value and the board of directors, which is at least forty percent independent, determines the value of other positions in good faith. ${ }^{101}$ Investment managers of unregistered funds have broader discretion in their choice of methods of and less oversight over their valuations of fund assets. This valuation impacts investment, disinvestment, and calculation of the manager's fee. Clearing of derivative positions under Dodd-Frank will limit this discretion by creating a mark to market requirement for derivative positions.

Since the manager generally receives a distribution or an allocation of ten to twenty percent of the increase in the value of the fund or each investor's separate account in the fund, the manager has an incentive to overstate the fund's value at the fee calculation intervals. The incentive fee accrues whether or not the fund has converted the gain into money by disposing of appreciated positions. Actual trades do not limit this valuation discretion significantly. ${ }^{102}$ Most hedge funds have more positions for which no market quotations are available than do registered investment companies. Fund documents do not require investment managers to return any portion of an accrued incentive fee when the value of the fund, or the investor's account, declines. Often the fund documents prohibit the manager from collecting an incentive fee again until the fund's value or the

\footnotetext{
${ }^{97}$ IAA Rule 205-3. Hedge fund adviser may charge incentive or result fees to "qualified clients" who, in the case of individuals, have at least $\$ 1.5$ million in assets, as opposed to the $\$ 1$ million asset threshold for "accredited investors" to whom issuers may sell private placement securities with any limit on the number of offerees or investors. See Securities Act Reg. D and Rule 501.

${ }^{98}$ Subject of course to the requirement that the selling broker or dealer know its customer.

${ }^{99}$ Exchange Act $\$ 10 \mathrm{~b}$ and rule $10 \mathrm{~b}-5$ under that statute.

${ }^{100}$ IAA $\$ 206$.

101 ICA Rule 2a-4.

102 That is, the fee is a function of the unrealized appreciation in the value of the fund.
}

Regulation of Private Equity, Hedge Funds, and Sovereign Wealth Funds

United States of America Report

Professor Henry Ordower, Reporter

Saint Louis University School of Law

$18^{\text {th }}$ Congress, International Academy of Comparative Law 2010 
investor's account value exceeds the level at which the fund previously accrued an incentive fee. ${ }^{103}$

This fee structure generates perverse incentives for the manager and increases investment risks for the investors. If a fund has retreated substantially in value from its highest value, operating the fund is no longer profitable for the manager. The manager will prefer to return the fund's capital to the investors, open a new fund, and concentrate efforts on raising capital and generating profits for the new fund, thereby capturing new incentive fees. Further, investors tend to withdraw their investment when the fund rapidly declines in value. The manager has an incentive to encourage those redemptions and to understate the value of the fund when there are substantial redemptions.

Following the redemptions, the manager may seek new investors and new investments from previous investors without the burden of the high water mark. ${ }^{104}$ There has been some discussion of regulating this practice, at least for registered advisors of "qualified client" funds by requiring managers to rebate accrued incentive fees when funds lose substantial value. ${ }^{105}$

Secrecy of the manager's portfolio and trading strategy poses additional risk to hedge fund investors. There is little to prevent the manager investing for the manager's own account in advance of the fund's large purchases or sales. ${ }^{106}$ Where a manager advises multiple funds, the manager may favor one fund over another in timing of investments so that one fund may condition the market for a trade by another fund. While these and other market conditioning practices violate conflict of interest and ethical standards for registered investment advisers and may violate antifraud statutes, they are difficult to detect and sanctions tend to be lax. ${ }^{107}$ Following recent investigations of the practices, the SEC and both the National Association of Securities Dealers and the New York Stock Exchange, which now are part of FINRA, broadened their rules to require additional disclosure on pricing and valuation and adopted codes of ethics for investment advisers. Despite new rules and substantial fines in some instances, none of the new rules seem to have eliminated the practices that have the effect of shifting portions of the investors' return on investment to the investment advisers. ${ }^{108}$

c. Theft and Fraud. If the objective of additional regulation is to protect even the very wealthy from pyramid schemes, promoter theft of investors' money, and other promoter frauds, rules under the Exchange Act antifraud provisions apply now, as do common law and state statutory fraud laws. The SEC had the power to investigate the Madoff pyramid for violation of the general antifraud rules, as there were ongoing purchases and sales of investment units in the form of interests in the fictitious fund or

\footnotetext{
${ }^{103}$ Hedge fund managers refer to that value as a "high water mark."

${ }^{104}$ To the extent that managers engage in this strategy intentionally, it is a fund management variation of "pump and dump".

${ }^{105}$ Referred to as a "claw back."

${ }^{106}$ One variation of an unethical practice known as "front-running."

${ }^{107}$ For a discussion of questionable market practices including front running late trading, market timing, and manipulative valuation see William A. Birdthistle, Compensating Power: An Analysis of Rents and Rewards in the Mutual Fund Industry, 80 TUL. L. REV. 1401 (2006).

${ }^{108} I d$. at $1406-7$.
}

Regulation of Private Equity, Hedge Funds, and Sovereign Wealth Funds

United States of America Report

Professor Henry Ordower, Reporter

Saint Louis University School of Law

$18^{\text {th }}$ Congress, International Academy of Comparative Law 2010 
Madoff's brokerage. Those interests are securities under the Exchange Act. ${ }^{109}$ A universal rule for independent custody of assets and bonding for employees of the manager and for the manager might reduce the number of assets thefts even from qualified purchaser funds. ${ }^{110}$ Extensions of some other limited protections such as an independent audit requirement for managed capital are possible added protections.

Dodd-Frank includes a new required for registered advisers to safeguard client funds and give the SEC rulemaking authority to require verification of assets under custody. ${ }^{111}$ The new requirements are much less onerous than a requirement of third party custody, as required for registered investment companies, and auditing of fund balances.

It may not only be hedge fund managers who object to new regulations that limit their flexibility and fees. Wealthy investors may find such regulation unnecessary because they have the sophistication to negotiate desirable arrangements and fear that regulation may cost the manager flexibility that might limit the investors' return. ${ }^{12}$

2. Risks for General Market Investors. Many of the same practices that endanger the value of investments in hedge funds also may affect participants in the financial markets who are not fund investors adversely. If a manager engages in market conditioning practices, including front running, market timing, and late trading, the advantage to the manager operates to the disadvantage to other participants in the financial markets. The larger the hedge funds over which the manager has trading control, the greater the manager's ability to use the fund's assets, borrowing power, and influence to capture for the manager or the fund or both advantages in trade execution, access to desired initial public offering allocations, and broker/dealer favored customer status. Funds with very large asset bases may engage in large trades or highly leveraged indirect trades through derivative positions that move the market in one direction or the other. While the activities of the managers and their hedge funds may not create systemic risk, ${ }^{113}$ those activities may diminish the profit or increase the losses of others artificially

\footnotetext{
${ }^{109}$ Exchange Act $\$ 10(b)$ and Exchange Act Rule 10b-5. Exchange Act $\$ 3(a)(10)$ defines the term security broadly in substantially the same manner as the Securities Act discussed supra in text accompanying note 34.

${ }^{110}$ Funds exempt from registration under ICA $\S 3(c)(7)$. Like the general antifraud provision, Exchange Act $\S 10(\mathrm{~b})$ and Rule 10b-5, absence of registration does not mean that any legal limitation exists for extending specific investor protection rules to unregistered funds. However, custodial arrangements are a source of profit for managers who deal with the fund honestly as well as dishonest managers.

111 Section 411 of Dodd-Frank.

${ }^{112}$ Interestingly, there has been considerable discussion and innuendo concerning Madoff clients with respect to why they did not suspect something was amiss. Part of the speculation has been that some of the larger clients and referrers knew the returns were consistently too high for the market but figured that Madoff was engaging in illegal and borderline trading strategies for the benefit of his investors. In addition to front running, he was using his power to position himself to capture favored executions from his brokers and to trade after hours.

${ }^{113}$ Current proposals of the Obama administration address the systemic risk from hedge funds and the trading of derivative positions rather than the impact of market conditioning practices on others trading in the market. Financial Regulatory Reform Proposals, supra note 31, at 43.
}

Regulation of Private Equity, Hedge Funds, and Sovereign Wealth Funds

United States of America Report

Professor Henry Ordower, Reporter

Saint Louis University School of Law

$18^{\text {th }}$ Congress, International Academy of Comparative Law 2010 
by forcing unexpected or sudden and temporary market movements that the hedge funds and their managers exploit to generate quick profits.

Greater transparency would make the market experts aware of the specific market influences of the hedge funds and their managers and better able to assimilate that information into pricing. Hedge fund portfolio and strategy information might acclimate the markets to specific manager's practices and prevent some sudden market movements. To the extent that regulatory proposals would force greater disclosure from funds and managers, other market participants would be able to distinguish artificial from actual events that affect the markets and filter them out of pricing and purchase/sale decisions. Loss of those advantages to the hedge funds and their managers would likely limit the profitability of the funds and lower fees for the managers.

New legislation requires greater transparency by requiring unregistered advisors to hedge funds and private equity firms to register. ${ }^{114}$ Registration include regular reporting of the advisors trading activities and the market positions of the funds they advise. The stated purpose for the registration and reporting is to enable the regulatory agencies to assess if any of the managers or funds pose general market risk. ${ }^{115}$ If they do, they may become subject to enhanced regulation.

\section{Risks for Counterparties and Lenders. Systemic Risks.}

a. Hedge Funds. To the extent that hedge funds utilize substantial borrowing and financial leverage in their investing activities, they pose an economic risk to their lenders and counterparties. With respect to borrowing, under rules of the Federal Deposit Insurance Corporation, banks remain subject to certain per borrower lending limits that prohibit banks from lending more than fifteen percent of their capital to a single borrower. ${ }^{116}$ In addition, under the Federal Reserve Bank's regulations governing the margin requirements for broker/dealer lending on margin securities, ${ }^{117}$ the general limit is fifty percent of value margin requirement and 150 percent for short sales. ${ }^{118}$ In addition, banks are subject to a maximum securities lending limit of 100 percent of value. ${ }^{119}$ Various exceptions exist for both margin requirements and overall lending limits. While hedge funds might borrow from other organizations that are not institutional lenders or broker/dealers - pension and profit sharing plans, charitable organizations, state and local governments, insurance companies, for examples - and issue notes to those institutions, lender monitoring of hedge fund's debt load is critical to preventing default. Regulated financial institutions must examine customers' financial statements before extending credit and would observe the presence of outstanding notes to other lenders. Nevertheless, a default by a particularly large hedge fund or several funds might jeopardize the stability of the lending financial institution.

\footnotetext{
${ }^{114}$ Section 403 of Dodd-Frank.

${ }^{115}$ Section 404 of Dodd-Frank.

11612 C.F.R. $\$ 32.3$.

${ }^{117}$ Federal Reserve Bank Reg. T, 12 CFR $\$ 220$.

${ }^{118}$ Id. 12 CFR $\$ 220.12$.

${ }^{119}$ Reg. U. 12 CFR $\$ 221$.
}

Regulation of Private Equity, Hedge Funds, and Sovereign Wealth Funds

United States of America Report

Professor Henry Ordower, Reporter

Saint Louis University School of Law

$18^{\text {th }}$ Congress, International Academy of Comparative Law 2010 
Off balance sheet financing makes it difficult to assess a hedge fund's debt load and thereby increases the hazards to lenders and other counterparties. Indebtedness from financial leverage in the form of various derivative positions is far less transparent than traditional borrowing activity and short sales. If the size and volume of the derivative positions is large, default by the hedge fund's counterparties, as well as default by the hedge fund itself, may render the hedge fund unable to pay its traditional borrowings. Only a small adverse movement in the markets may cause an extremely leveraged hedge fund to default on its derivative positions, as well as its traditional indebtedness, so that the hedge fund poses a risk to its derivative counterparties. Dodd-Frank will limit some of the off balance sheet financing by requiring reporting of credit exposure ${ }^{120}$ and clearing of derivatives. ${ }^{121}$

b. Private Equity Funds. In the context of corporate takeovers, private equity funds borrow heavily to fund the acquisition of the shares of the target company. As the acquisition is a leveraged buyout, the private equity fund's intention is to service the acquisition indebtedness with the target's cash flow or proceeds from the sale of target's assets. Since the acquisition indebtedness may equal or exceed the historical value of the target, and, almost invariably exceeds the liquidation value of the target, as the private equity borrower anticipates that it will be able to improve the target's profitability, the margin of error is quite thin. Default is likely. In many instances, the private equity fund will renegotiate the terms of the indebtedness as the target proves less profitable than anticipated. ${ }^{122}$

c. Systemic Risk. Leverage, whether for the purpose of funding a private equity fund's corporate acquisition or a hedge fund's trading activities, may generate systemic risk. A borrower's or derivative counterparty's default may cause the lender or counterparty to default on its own obligations. Those defaults may lead to further defaults of other counterparties and lenders to the original counterparties and lender. A default in a large credit facility, whether direct lending or derivative, has the potential to cause a domino effect. Additional systemic risk follows short selling practices. Market professionals have observed that short selling exerts downward pressure on the value of the securities. Loss in value of securities may cause holders of long positions to become unable to meet margin calls on those securities and, ultimately, cause the broker/dealer margin lender to default on its obligations. Market collapse may follow if sufficient defaults occur within a short period, as happened in late 2008.

It is difficult to evaluate what role hedge and private equity funds played in the market events in 2008. They certainly were not the most visible actors but may have been the least transparent ones. While hedge funds have engaged in a significant volume of derivative trading, they have not been the only participants in those markets. Banks,

\footnotetext{
${ }^{120}$ Section 204(b)(3) of the IAA, as amended by section 404 of Dodd-Frank.

${ }^{121}$ Title VII and VIII of Dodd-Frank.

${ }^{122}$ See discussion of risks from target restructuring in the text accompanying note 127 infra.

Regulation of Private Equity, Hedge Funds, and Sovereign Wealth Funds

United States of America Report

Professor Henry Ordower, Reporter

Saint Louis University School of Law

$18^{\text {th }}$ Congress, International Academy of Comparative Law 2010
} 
insurance companies, charitable organizations, pension and profit sharing funds, and governmental entities all sought to enhance their portfolios with derivative trading. ${ }^{123}$

Perhaps the most visible derivative event in 2008 was American International Group's inability to pay on its credit default swaps. AIG sold many credit default swaps on which it was not hedged and was unable to meet its obligations. Those swaps resembled AIG's core business of risk insurance products, but their volume exceeded normal risk insurance exposure because the swaps did not require that the counterparty to the swap have any insurable interest in the reference debtor or debt instrument. ${ }^{124}$ If hedge funds were major purchasers of credit default swaps, their participation in that market augmented the systemic risk. Media reports did not disclose that hedge funds were major AIG counterparties in the credit default swaps. ${ }^{125}$

Subprime lending and accompanying mortgage defaults drove the market event in 2008. ${ }^{126}$ As the economy weakened, those borrowers began to default on their mortgages. As interest rates rose, adjustable rate mortgages reset their interest rates and borrowers defaulted. Similarly, governmental entities and other borrowers were unable to find a market for resetting the interest rate on their auction rate securities and were required to pay the higher rate that the instruments required in the absence of a market reset. The market for auction rate securities became illiquid. Those events had little to do with hedge funds or private equity funds.

4. Risks to Target Enterprises, Employees, and Communities. Private equity funds and, in limited cases, hedge funds that acquire large stakes in an enterprise pose significant risks to those enterprises, their workers, and the communities of which they are a part. Leveraged acquisitions threaten enterprises by saddling them with indebtedness that, absent a substantial increase in profitability, will drive the enterprises into bankruptcy. But like questions of derivative regulation, the issue of the impact of corporate takeover is not a private equity fund issue.

Whenever there is a leveraged acquisition, the acquirer, whether another corporate enterprise, an individual, or a private equity fund, seeks to capture the hidden value of the target by disposing of inefficient features of the enterprise and restructuring the

\footnotetext{
${ }^{123}$ Compare the Technical Committee of the International Organization of Securities Commissions, Hedge Funds Oversight Final Report 8 (available at http://www.iosco.org/library/pubdocs/pdf/IOSCOPD293.pdf) (making 6 recommendations for additional regulation but acknowledging that hedge funds were not significant contributors to the market downturn in 2008).

${ }^{124}$ A holder of a bond might purchase a credit default swap to protect against default on the bond or any lender might buy a swap to protect against default by the borrower. In those instances, the bondholder or lender has an insurable interest and could buy credit insurance or require the borrower to buy credit insurance to protect the bondholder or lender. The derivative credit default swap has a reference borrower or instrument, but the purchaser of the swap need not have any interest in that borrower or instrument to be entitled to a payment in the event of a default.

${ }^{125}$ Mary Williams Walsh, Inquiry Asks Why A.I.G. Paid Banks, THE NEW YORK TIMES B4 (March 27, 2009)

${ }^{126}$ Contrary to the implication of the term, subprime lending refers to lending to less creditworthy individuals than traditional home mortgage borrowers. Generally, subprime loans require substantial fees and high interest rates.
}

Regulation of Private Equity, Hedge Funds, and Sovereign Wealth Funds

United States of America Report

Professor Henry Ordower, Reporter

Saint Louis University School of Law

$18^{\text {th }}$ Congress, International Academy of Comparative Law 2010 
remainder of the enterprise to enhance its profitability. In some instances, the acquirer will sell parts of the enterprise resulting in the loss of employment and exit of that part of the enterprise from the community. Restructuring may cost jobs in the short run, but, if successful, may lead to a more efficient, profitable, and expanding enterprise with new job opportunities. Private equity funds are no more ruthless in breaking up an enterprise and no less patient in restructuring the enterprise than are other acquirers, although they may have less commitment to the enterprise and the community than if existing management acquired the enterprise. Delaware court decisions suggest that management resist takeovers in order to protect the corporate culture and the community. ${ }^{127}$

Corporate acquisitions of other major corporations may not depend upon leveraged acquisitions as much as other acquirers. However, those acquisitions may have more impact on employment in a community and support for culture in the community than a private equity fund acquisition. The corporate acquirer has a headquarters elsewhere and is likely to shift management functions to its existing headquarters to minimize management redundancies. That shift not only affects local employment but tends to diminish corporate support for local cultural institutions. ${ }^{128}$

F. Sovereign Wealth Fund Overview. As state-owned investment vehicles, SWFs are exempt from taxation in the United States as long as they do not engage in commercial activity. ${ }^{129}$ Most SWFs are independent entities with a board of directors and managers who are not necessarily government officials. ${ }^{130}$ Excess foreign currency reserves provide the primary funding for SWFs and stabilize revenues from the sale of commodities such as oil or natural gas. While SWFs historically invested in traditional financial instruments like United States Treasury Bonds, fund managers seeking higher returns and greater diversification turned increasingly to equities. In the wake of a weak economy, SWFs made large investments in Morgan Stanley, Citigroup, Blackstone, Carlyle and Merrill Lynch. In 2008, Abu Dhabi Investment Authority invested \$7.5 billion in Citigroup, Inc, the China Investment Company invested $\$ 5$ billion in Morgan Stanley, and Singapore's Temasek Holdings invested \$6.2 billion in Merrill Lynch \& Co. Inc. $^{131}$

1. Principal Concerns. While SWFs have existed since the 1950 s without attracting regulatory interest, they have begun to face scrutiny because they have grown rapidly in recent years. In 1990, estimates pegged SWFs at approximately $\$ 500$ billion in

\footnotetext{
${ }^{127}$ Weinberger v. UOP, supra note 28.

${ }^{128}$ In St. Louis, Nestle's acquisition of Ralston Purina in 2001 and InBev's acquisition of Anheuser Busch in 2008 both had significant adverse impacts on the St. Louis community and employment in St. Louis, as well as diminished support for St. Louis cultural institutions.

${ }^{129}$ IRC $\S 892(a)$. See Victor Fleischer, A Theory of Taxing Sovereign Wealth, 84 N.Y.U.L.

REV. 440 (2009) (arguing that the exemption is unjustified and proposing methods for taxation).

${ }^{130}$ Michael S. Knoll, Taxation and the Competitiveness of Sovereign Wealth Funds: Do Taxes Encourage Sovereign Wealth Funds to Invest in the United States 3-4 (U of Penn, Inst for Law \& Econ, Research Paper No. 08-28, 2008), available at http://ssrn.com/abstract=1291878.

${ }^{131}$ Joint Comm. on Taxation, 110th Cong., ECONOMIC AND US INCOME TAX ISSUES RAISED BY SOVEREIGN WEALTH FUND INVESTMENT IN THE UNITED STATES 29

(Comm. Print 2008) (hereafter JCT).
}

Regulation of Private Equity, Hedge Funds, and Sovereign Wealth Funds

United States of America Report

Professor Henry Ordower, Reporter

Saint Louis University School of Law

$18^{\text {th }}$ Congress, International Academy of Comparative Law 2010 
assets. ${ }^{132}$ Today, estimates show them controlling some $\$ 3.22$ trillion in assets. ${ }^{133}$ According to the IMF, SWFs could reach $\$ 6-10$ trillion by $2013 .{ }^{134}$ High oil prices, financial globalizations, and sustained, large global imbalances all contributed to oil exporters and Asian countries accumulating substantial foreign assets. ${ }^{135}$ The size of the funds has caused policymakers to express concern that SWFs will invest in ways that cause volatility in markets and disruptions in economies.

Like hedge funds, SWFs tend to be opaque. While there is some information on SWFs, there is no uniform public disclosure of the assets, strategies, and governance of SWFs. ${ }^{136}$ Few SWFs publish information on their size, returns, composition of their portfolios, investment objectives, and proxy voting policies and some countries specifically prohibit any public disclosure of their SWF activities. ${ }^{137}$ Lack of transparency makes it difficult to access the inflow of capital from SWFs. Foreign investors, including governments, private entities, and individuals, may have owned over \$20 trillion of United States assets in 2007. ${ }^{138}$ The Joint Committee on Taxation estimated that SWFs accounted for at least $\$ 21.5$ billion of that investment, but that estimate may understate SWF investments substantially. ${ }^{139}$

More important than the possibility that the size and opaqueness of SWFs may undermine market stability is the ability of the funds to use their economic power to pursue political goals. While the funds serve primarily to protect the economic future of their home countries, political objectives may inform investment decisions. Governments might exploit the large pools of capital in the funds to secure access to strategic assets, including natural resources and defense-related technologies, and threaten national security in the United States. ${ }^{140}$ Nevertheless, there has been no evidence that SWFs are politically motivated investors. ${ }^{141}$

2. New Outlook. Before the 2008 financial crisis, policymakers had expressed concerns about SWFs. Currently, some policymakers view SWFs as a stabilizing force in the economy, as SWF investments have provided the necessary liquidity in some sectors.

\footnotetext{
${ }^{132}$ Simon Johnson, The Rise of Sovereign Wealth Funds, 44 FIN. \& DEV. 56, (2007), available at http://www.imf.org/external/pubs/ft/fandd/2007/09/straight.htm.

${ }^{133}$ Research and Markets: 2009 Sovereign Wealth Fund Review as they Currently Control an Aggregate $\$ 3.22$ tn in Assets Under Management, (Reuters Apr 1, 2009), online at http://www.reuters.com/article/pressRelease/idUS175494+01-Apr-2009+BW20090401(visited July 24, 2009).

${ }^{134}$ Mark Allen and Jaime Caruana, eds, Sovereign Wealth Funds - A Work Agenda 6 (IMF Feb 29, 2008), online at http://www.imf.org/external/np/pp/eng/2008/022908.pdf (visited June 15, 2009).

${ }^{135} \mathrm{Id}$. at 4.

${ }^{136} \mathrm{Id}$. at 8.

${ }^{137}$ Government Accountability Office, Sovereign Wealth Funds: Publicly Available Data on Sizes and Investments for Some Funds Are Limited, GAO-08-946, 4 (Sept 2008), online at http://www.gao.gov/news.items/d08946.pdf (visited July 24, 2009).

${ }^{138} \mathrm{Id}$. at 5 .

${ }^{139}$ JCT supra note 2, at 27.

${ }^{140} \mathrm{Id}$. at 30 . An additional concern is that SWFs may compete unfairly with private actors through government guarantees of financial commitment. Id. at 31. Those funds would become taxable in the U.S. if they engage in commercial ventures. IRC $\S 892(a)(2)$.

${ }^{141} I d$.
}

Regulation of Private Equity, Hedge Funds, and Sovereign Wealth Funds

United States of America Report

Professor Henry Ordower, Reporter

Saint Louis University School of Law

$18^{\text {th }}$ Congress, International Academy of Comparative Law 2010 
Yet, concern with the lack of transparency lingers. Comprised of 26 IMF member countries with SWFs, the IWG developed the "Santiago Principles" in October 2008 to address the lingering concern that SWFs lacked transparency and regulatory oversight. ${ }^{142}$ The Santiago principles "identify a framework of generally accepted principles and practices that properly reflect appropriate governance and accountability arrangements as well as the conduct of investment practices by SWFs on a prudent and sound basis."143 The IWG members have committed to implementing the Santiago Principles, which include a commitment to financial objectives and guidelines for better transparency and disclosure of SWF relationships with the sponsoring government. As implementation is voluntary, non-compliance carries no sanctions.

3. United States Regulation of SWF Investment. While the United States is open to foreign investment, laws limit or restrict foreign investments in banking, communications, transportation, natural resources and energy, agriculture, and defense in order to protect national security. ${ }^{144}$ In addition, foreign investors are subject to review by the Committee on Foreign Investment in the United States (CFIUS). CFIUS, which was codified by the Foreign Investment and National Security Act of 2007 (FINSA), ${ }^{145}$ is a committee of the United States government that reviews the national security implications of foreign investments. ${ }^{146}$ The CFIUS monitors overseas acquisitions of ten percent or more of a domestic company's total ownership. CFIUS has shown particular interest in transactions where the target United States company has classified contracts with the United States government or technologies critical to national defense. ${ }^{147}$ Under the CFIUS process, investors file a voluntary notice, often even when it appears that the transaction does not involve a controlling ownership. After notice is received, CFIUS begins a thirty day National Security Review. ${ }^{148}$ Following this review, CFIUS may either allow the transaction to proceed or undertake a second, forty-five day National Security Investigation. ${ }^{149}$ CFIUS has approved the vast majority of notified transactions during the initial thirty-day period but CFIUS has begun to subject a growing number of transactions to the forty-five-day investigation. ${ }^{150}$ While CFIUS has rejected few acquisitions, investor SWFs have abandoned a number of investments because of the CFIUS process. For example, in 2006, Check Point, an Israeli company, cited the CFIUS

\footnotetext{
${ }^{142}$ See Int'l Working Group of Sovereign Wealth Funds, Sovereign Wealth Funds: Generally Accepted Principles and Practices: "Santiago Principles", 28 (Oct. 2008), available at http://www.iwgswf.org/pubs/eng/santiagoprinciples.pdf (listing IWG members). The acronym "GAPP” refers to the principles. 
process as the basis for abandoning a deal to acquire a United States company, Sourcefire, which produced intrusion detection technology that many United States government departments in various sensitive contexts utilized. ${ }^{151}$ For the SWFs which do not voluntarily give notice to the CFIUS, there is no time limit on the President's authority to investigate and reject even a completed SWF acquisition. ${ }^{152}$

Since the FINSA changes, CFIUS often conditions its approval of SWF investments on the signing of a mitigation agreement which might stipulate that the SWF remain a passive shareholder and not seek representation on the target's board of directors. ${ }^{153}$ For example, as a condition to its $\$ 7.5$ billion investment in Citi, Abu Dhabi's SWF agreed "not to own more than a $4.9 \%$ stake in Citi, and will have no special rights of ownership or control and no role in the management or governance of Citi, including no right to designate a member of the Citi Board of Directors." " Recently, SWFs have structured their investments in United States financial institutions to avoid CFIUS review. In those instances, the SWFs take no board seats and acquire less than a ten percent interest. The funds also publicly disclaim any ability to oversee or engage in the management of the company or business. ${ }^{155}$

SWFs must abide by the same rules as private pools of capital. SWFs are subject to the antifraud provisions of the securities laws, the antitrust laws, and state corporate laws. If SWFs acquire a five percent or greater equity stake in a public company, they must make disclosures in accordance with the Exchange Act. ${ }^{156}$ In order to avoid disclosure requirements pursuant to the Exchange Act, most SWFs acquire less than five percent of any United States company. State laws protect against those SWFs with a member on the board. Directors owe a duty of care and loyalty to the company and stockholders which requires them to make decisions based on the best interests of the company and its stockholders. State statutes and legal precedents prohibit SWF managers from passing confidential information that they might gain from their activities on behalf of the fund. Trading of shares when the SWF possesses non-public information would violate federal antifraud rules under the securities laws. ${ }^{157}$

${ }^{151} I d$. at 5 .

${ }^{152} I d$. at 2

${ }^{153}$ Paul Rose, Sovereigns As Shareholders, 87 N.C. L. REv. 128 (2008).

${ }^{154} \mathrm{Id}$.

${ }^{155} \mathrm{Id}$.

${ }^{156}$ Exchange Act §13(e), 15 U.S. C. §78a-???

${ }^{157}$ Exchange Act Rule 10b-5.

Regulation of Private Equity, Hedge Funds, and Sovereign Wealth Funds

United States of America Report

Professor Henry Ordower, Reporter

Saint Louis University School of Law

$18^{\text {th }}$ Congress, International Academy of Comparative Law 2010 
Appendix to United States of America Report on Hedge Funds, Private Equity Funds, and Sovereign Wealth Funds

XIIIth Congress of the International Academy of Comparative Law

\section{General Reporter's Questionnaire}

Dear Colleagues,

According to the letter I received from the secretariat, the topic, which we are supposed to deal with, is entitled

"La réglementation des fonds spéculatifs/ The regulation of private equity, hedge funds and state funds"

No need to state that the English translation is substantially from the French title.

These are three relatively different subjects among which it will be difficult to find a common denominator. The most likely common element is to be found in the behaviour of these funds as shareholder in investee companies (see part 2).

Therefore I propose to open three serious of questions, the first one relating more to the organisation of these funds, the second more related to their action as shareholders or in society in general. The SWF are then in a separate class.

1. Legal issues relating to hedge funds (HF) and private equity funds (PEF).

1. The existence of a legal regime, whether in regulation or outside regulation could be mentioned briefly. Analysis of the different regulations relating to hedge funds can i.e. be found in the recent IOSCO consultation paper.

The question will arise as to the definition of HF or PEF: I would propose that we do not attempt to draw up a definition, as this has proved impossible by several international regulatory bodies. Especially for $\mathrm{HF}$, the formula is so elusive and adapts so rapidly to market circumstances that any definition would run behind the facts. One can refer to attempts made by i.a. the IOSCO paper mentioned in the attached list.

In the more recent terminology, HF are referred to as "private pools of capital" and I'm not sure that is a right designation.

2. If there is regulation specifically applicable to HF and PE funds, please mention the nature and general features of the regulation, e.g. whether this is public or private regulation, and in the latter case, if it is followed up in practice, and enforced by some external body. Most of the HF are registered in some tax heaven: why is this feature considered important for the application of the regulation in your jurisdiction?

General Reporter's Questionnaire

Regulation of Private Equity, Hedge Funds, and Sovereign Wealth Funds

Appendix to United States of America Report

$18^{\text {th }}$ Congress, International Academy of Comparative Law 2010

Appendix Page i 
3. How many of these funds are registered?

4. As to the general purport, it would be useful to indicate whether the regulation addresses the manager, or also the fund, as both systems are practised. The main subjects that are covered in the regulation should also be mentioned, e.g. whether there is registration of the manager, what are the criteria applicable to it, are there restrictions with other activities e.g. asset management for other funds that HF.

5. In the future it is likely that the regulation will be more developed about the creation of HF and PEF: own funds, gearing ratio's, conduct of business rules, information and /or disclosure rules, accounting provisions, rules on manager's remuneration.

6. The - public - distribution of shares in these funds deserves some mention, as in many states, these funds cannot be offered to the public. In fact they may be offered indirectly, through Funds of Hedge Funds (FoHF), through insurance products, or in other forms. The disclosure and other investor protection rules could be different depending on the legal structure chosen. Here a few mentions would be useful. What is the status of this debate about "alternative products," or " substitute products"? Some in the EU consider extending the MiFid ${ }^{1}$ rules to all investment products: what is your reaction to this?

7. Have there been cases of misselling of HFs or FoHFs? Were these decided in court? Have investors been indemnified?

3. Except in case of public distribution, it would be useful to have some idea about the nature of the holders of shares in these HF or PEF: traditionally, it was said that these were wealthy individuals, but it appears that apart from FoHF, institutional investors (pension funds, insurance companies, investment funds) are increasingly acquiring shares in these funds: is the protection regime sufficient, and should regulation contribute to improve the position of these not always so sophisticated investors.

4. Where do you stand in this debate about extending the protections to a wider public that these so-called sophisticated investors? This is not typical for HF but has caused most concern if HF were involved.

5. Do investors in HF and PEF have sufficient information, whether on entry or on a continuous basis? Should this be left entirely to the freedom of contract or should the law provide for a generic measure. As HF are increasingly placed with a large public but even without a public issue how should the information system not be adopted? Continuous information on the evolution of the portfolio is even more important, as investors often are left in the dark until it is too late.

6. If in your jurisdiction the managers have to be licensed, what are the conditions for obtaining the license: a few items might be:

\footnotetext{
${ }^{1}$ Esp. rules on know your customer, suitability, and so on.

General Reporter's Questionnaire

Regulation of Private Equity, Hedge Funds, and Sovereign Wealth Funds

Appendix to United States of America Report

$18^{\text {th }}$ Congress, International Academy of Comparative Law 2010
}

Appendix Page ii 
a.

b.

c.

d.

e.

f.

g.

Fit and proper character of the managers

Rules on conflict of interest

Rules on risk management: these have been considered too weak Internal rules on valuation: contractual rules or IFRS?

Internal rules on compliance

Internal rules on asset segregation, on due diligence of investee

Is there an internal and /or an external audit

And are these conditions verified by an external body initially upon registration and from time to time?

Some of these issues are particularly important for PEF: valuation, conflicts of interest are well known problems. How does your legal system deal with these?

7. The recent crisis has indicated that HF may be exposed to substantial systemic risk, and hence that central banks, as systemic and prudential supervisors want to obtain data about their portfolios and their behaviour in the markets of at least the largest of these funds:

a.

Do HF and PEF usually inform these authorities about their portfolio, even if only some time ex post?

b.

Have these authorities access through their prime brokers? And can the information be aggregated?

c. Is apart from leverage, the built up of important positions in certain assets that could trigger significant price movement upon a certain liquidity need, a point of concern?

d.

Should these funds disclose their portfolios publicly?

8. What is the position on the remuneration of the HF managers: is there a public debate in your country and are there proposals to improve on this point?

9. $\quad$ PEF, and to a lesser extent, HF have been accused to destroy the companies they invest in: the so-called "locust" phenomenon. Is this a public debate in your country and have the authorities dealt with it? What answers have been given, or what remedies could apply? (this could also be dealt with in part 2)

10. Market abuse by HF is often mentioned: are there cases that have been reported in your country? Were these specific to HF activity, e.g. related to the volume of their business in a given market? Is there a policy dealing with rumours?

11. Clauses about the withdrawal from HF or PEF: how are these structured? How did they work in the downward markets? Have investors complained about unjust treatment on exit? What techniques have been used to postpone the exercise of exit rights?

Part II: the social role of the Hedge funds, Private Equity Funds

General Reporter's Questionnaire

Regulation of Private Equity, Hedge Funds, and Sovereign Wealth Funds

Appendix to United States of America Report

$18^{\text {th }}$ Congress, International Academy of Comparative Law 2010

Appendix Page iii 
2.1 What has been the role of PEF in your country: there are widely divergent opinions, the PEF stating themselves that they mainly offer management services, with an equity investment to maximise their returns.

On the other hand, HF and PEF have been accused of destroying firms through excessive leverage and appropriation of financial substance. What is the prevailing opinion on this subject in your jurisdiction?

They also have been accused of destroying employment ${ }^{2}$ : what is the prevailing opinion in your country.

Have measures been taken to curb these negative consequences, e.g. regulating closures of plants, or massive lay-offs? What is their effectiveness? Have these aspects been litigated in court?

Is there any government's measure that has been taken, or is envisaged on these topics? Is there voluntary restraint by the PEF themselves? What kind of measures have they taken: Reducing leverage, duration of investment, etc

2.3 HF and to a more exceptionally PEF have been known for their activist stand as shareholders, although they are by no means the only ones. Usually they put the board under pressure so that it would adapt its policies to their views.

How should board react to these attempts? What are the limits for boards to enter into contact with these activist shareholders?

2.4 What are the techniques used to pursue their position even owning only a minor block of shares?

Proxy voting

Voting agreements

Alliances with institutional investors

Short sales as an activist instrument

Media alerts

2. 4. Can any of the following be used as techniques to exercise pressure by HF or PEF

-Right to call the general meeting

-Motion to dismiss the board of directors

- Motion to split-up the company, or to merge it with another

\footnotetext{
${ }^{2}$ From European Venture capital Association:

Investments by European private equity and venture capital firms amounted to $€ 73.8 \mathrm{bn}$ in 2007 , and approximately 5,200 European companies received private equity investments. About $85 \%$ of these companies have fewer than 500 employees. Studies show that between 2000 and 2004 European private equity and venture capital financed companies created 1 million new jobs, which translates to a compound annual growth rate of 5.4\% per year (eight times the EU25 total employment rate of 0.7\%). Between 1997 and 2004 , the average employment growth in buyout-financed companies was $2.4 \%$, compared to $30.5 \%$ for venture-backed companies.
}

General Reporter's Questionnaire

Regulation of Private Equity, Hedge Funds, and Sovereign Wealth Funds

Appendix to United States of America Report

$18^{\text {th }}$ Congress, International Academy of Comparative Law 2010

Appendix Page iv 
-Motion to close down certain parts of the business, or to sell it off to third parties (major disposals).

Do these decisions belong to the competence of the general meeting or can the board of directors take them.

Is the present threshold to call a general meeting widely accepted or are they criticised.

2.5. Are HF known for gaining support to their ideas

- By using the media: are measures against equity manipulation effectively put in action? Should public announcements about forthcoming action not be subject to the same rules as for board announcements see: reg FD)

-Should there not be more transparency about the identity of the owners of voting rights in general? And about the shareholders in activist funds (concert action)

- Companies generally do not know the names of their shareholders due to the indirect ownership structures; what measures should be taken to ensure that boards have the names of their shareholders, and engage in a debate with them. What is being done about it?

- Important shareholders hide their ownership by the use of derivatives or complex financial constructions; by entering into equity swaps, contracts for difference and similar transactions

- By creating secret alliances with other shareholders, or by hiding their own voting position: what are the techniques usually followed? .

P.M. is there a debate in your jurisdiction about "empty voting" and how do you think this can be solved.

2.6 What defences can boards use to resist pressure from activist shareholders?

Is there a board neutrality rule, or only in Takeover bids?

Some advise to engage with the activists: defensive action is a last resort: Can boards communicate with activist shareholders, or should they abstain on the basis of equal treatment?

2.8. Some actions by minority shareholders are close to greenmail: does this happen in your country, what is the attitude of the courts and what can be done about it? What is the liability of directors in giving in to greenmail? Disclosure?

\section{On PEF}

2.9. Does your legal system recognise an obligation of the shareholders to act in the interest of the company, or to can he act in his own selfish interest?

Does a shareholder have to act taking into account the respect for the interest of other fellow shareholders (fiduciary duty of the control shareholder)?

Part 3 the sovereign wealth funds

General Reporter's Questionnaire

Regulation of Private Equity, Hedge Funds, and Sovereign Wealth Funds

Appendix to United States of America Report

$18^{\text {th }}$ Congress, International Academy of Comparative Law 2010

Appendix Page V 
The notion of SWF is somewhat ambiguous: the aspect discussed here refers to the fact that foreign entities are owned by a foreign state and/or act on the orders of a foreign state. Some of these may be specific funds, funded out of excess foreign exchange reserves; other may be longstanding companies with a "public mission".

The potential detrimental policy influence has been at the centre of the debate, although the sheer size of their portfolio's and the lack of transparency may also be mentioned as points of concern. In case of difficulty, position may be imposed outside the boundaries of company law, but by e.g. the rules protecting direct foreign investment.

The Subject has now found a new equilibrium due to the financial crisis. The Santiago rules have also contributed to calming the debate.

Does your country regulate the activity of SWF and in which way?

Are there figures available about the inflow of capital coming from SWF?

Can you briefly describe some cases in which access to SWF have been refused, indicating the grounds on which this refusal was based.

Have you in your legal order introduced procedures - possibly generally applicable - that are applied to SWF and ensure openness of their activity.

Have SWF published their policy objectives, whether in general or upon a specific investment. Do they publish their voting polices, and the way these are implemented

Do SWF usually delegate a member to the board? Are there special rules applicable to that member e.g. with respect to secrecy?

Should investee companies include a passage in their annual reports about the presence of a SWF and its action within the investee company? Or on the way the SWF has voted

Have there been mechanisms introduced reviewing, or surveilling the activity deployed by SWF in investee companies?

Bibliography

Hedge Fund consultation paper EU Commission Febr 09

http://ec.europa.eu/internal_market/consultations/docs/hedgefunds/consultation_paper_en .pdf

Prada,M. Discours, http://www.amf-france.org/documents/general/7603 1.pdf

Proposed Elements of International Regulatory Standards on Funds of Hedge Funds Related Issues Based on Best Market Practices; http://www.iosco.org/library/pubdocs/pdf/IOSCOPD281.pdf

UK: Hector Sants' speech:

http://www.fsa.gov.uk/pages/Library/Communication/Speeches/2008/ 1022 hs.shtml

General Reporter's Questionnaire

Regulation of Private Equity, Hedge Funds, and Sovereign Wealth Funds

Appendix to United States of America Report

$18^{\text {th }}$ Congress, International Academy of Comparative Law 2010

Appendix Page vi 


\section{Forthcoming regulation in the EU and in the US(March-April 2009)}

On SW : http://www.iwg-swf.org/pubs/gapplist.htm: Santiago principles

On HF: http://www.hfsb.org/: HF standards board

A clearinghouse system for derivative products limits market flexibility, as standardized contracts and quantities do not necessarily fulfil the needs of participants in those markets. In the late 1990s, the IASD created a standardized contract for derivatives. Users of the standard contract tended to modify it terms so substantially through the contract schedules that the standard form was left only as a skeleton to provide some inconsequential boilerplate language and to remind uses or of the types of terms that they needed. For simple derivatives like a fixed to floating interest rate or currency to currency swap that have straightforward business uses, standardization and a clearinghouse might work well, but standardization will eliminate many complex products. As a policy matter, those complex structures may be undesirable so that loss of them might not be so bad. 